\title{
MUSSEL CULTURE
}

$$
\begin{aligned}
& \text { BAIT SUPPLY } \\
& \text { W LICALDERWOD }
\end{aligned}
$$

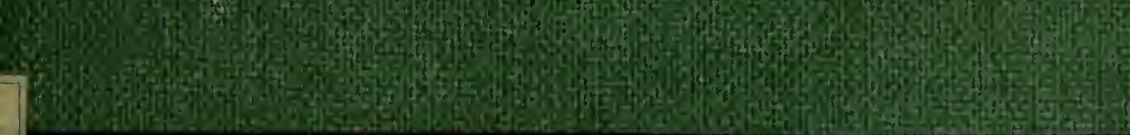

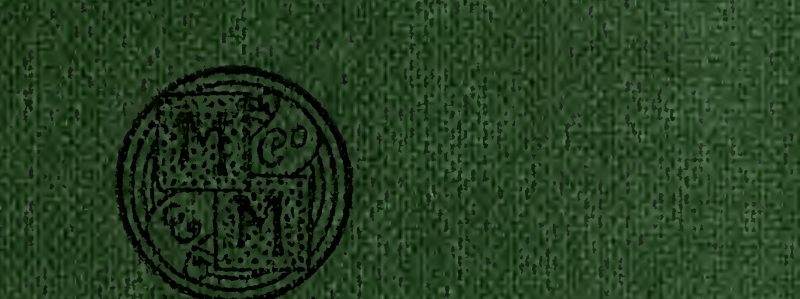

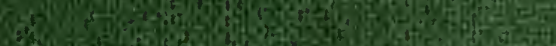
Qtons 50 . 
moll.

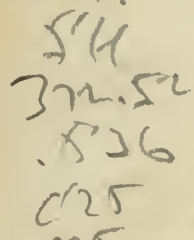

Museum of Comparative Zoölogy.

$$
\begin{aligned}
& \text { Ho } 13,46 q \\
& \text { deposited by alex. agassiz. } \\
& 30 \text { sept.' } 95 .
\end{aligned}
$$

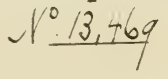




\section{Empt a Bay throry

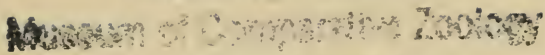

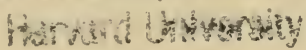

$$
\text { SLP }: 402)
$$




\title{
MUSSEL CULTURE
}

AND

\section{THE BAIT SUPPLY}

WITH REFERENCE MORE ESPECIALLY

TO SCOTLAND

Yieliam BY
W. L. CALDERIVOOD, F.R.S.E.

\author{
瓦ondon \\ MACMILLAN \& CO. \\ AND NEIV YORK \\ Sm 1895
}


Edinburgh: T. and A. Constable, Printers to Her Majesty. 


\section{PREFACE}

I HAVE been induced to write the following pages in the hope that the urgent need for an increased supply of mussel bait may be more generally recognised, that the interests of line fishermen may be promoted, and the food-supply of the country thereby increased.

My belief is that a systematic cultivation of our foreshores must be attempted before long, and that, on this account, a service may be rendered by the publication of a manual dealing with the natural history of the mussel, the practical aspects of its culture, and the legal questions bearing on the ownership and leasing of scalps.

While criticising the wasteful and ruinous treatment of our mussel beds in the past, I have nevertheless refrained from attempting to develop any detailed scheme of improvement, since this 
seems to me to fall primarily within the scope of purely Parliamentary action.

My main object has been to gather together such information as may be of use in the actual practice of culture.

In reviewing the present condition of our bait beds, I have specially mentioned thirty localities where important scalps exist, or have existed. Although these beds are entirely confined to the Scottish coast, the remarks as to the treatment of scalps are equally applicable to England and to Ireland.

I am much indebted to a friend in Glasgow for kindly reviewing the chapter dealing with the legal aspects of shell-fish fisheries.

I am also indebted to the Fishery Board for Scotland for granting me permission to add, as an appendix, the official Regulations and Instructions for those desiring to apply for special Fishery Orders.

\section{W. L. CALDERIVOOD.}

7 NAPIER RoAD,

EdINBURGH, December 1894 . 


\section{CONTENTS}

\section{CHAPTER I.}

MUSSEL BAIT-SUPPLY AND DEMAND.

PAGE

Public Shell-fish Beds threatened with extinction-Mussels as Bait of more importance than Oysters-Evidence of Mussel and Bait Beds Commission-Care of Shell-fish in France-Evidences of lack of Bait in ScotlandBaits, natural and artificial-Length of Lines to be supplied with Bait-Quantity and Value of Mussels landed in Scotland-Mussels from Holland-Decline of number of Line-caught Fish . . . . . I-I8

\section{CHAPTER II.}

PAST AND PRESENT MUSSEL BEDS OF SCOTLAND.

Short description of principal Mussel Beds of ScotlandGreat stretches of coast unprovided with Mussel Beds -Many Beds supplying merely a local demand-Many Beds ruined by over-fishing, neglect, and raidingRemaining patches in Moray Firth capable of great increase if cultivated 


\section{CHAPTER III.}

THE NATURAL HISTORY OF THE MUSSEL, AND THE TREATMENT OF BAIT SCALPS.

PAGE

Particular points of natural history of Mussel to be attended to-Classification and Anatomy-Spawning or 'Spatting'-Climatic conditions-Rate of Growth-Feeding in salt and fresh water-Overcrowding on Beds-High tidal Beds and deep-water Beds-Natural habitat of Mussel-Natural enemies-Floods, shifting sands, gales, frost-Favourable Conditions and Treatment of Scalps-Not to be long uncovered by tide-Transplanting-Cropping Beds in rotation-Use of rake rather than dredge-Rake in use at St. Andrews described - The Riddle - Use and description of, at King's Lynn-Statements as to probable success of Mussel Farming-Initial Expenditure repaid in about four years

\section{CHAPTER IV.}

THE FRENCH BOUCHOT SYSTEM OF CULTURE.

History and Origin of Bouchot System-Description of Modern Structure-Treatment of Mussels in Bouchots -Grown for Food rather than Bait-Experimental Bouchots erected in this Country-Unsatisfactory Results-Auxiliary uses of the Bouchot in this CountryCultivation by Bedding more suitable for Bait production 


\section{CHAPTER V.}

LEGAL ASPECTS OF THE SHELL-FISH FISHERIES.

PAGE

Territorial and Extra-territorial Water-Rights of taking

Shell-fish-Public and Private Rights to Foreshores-

Shell-fish Scalps the Private Property of the Crown-

-The Transfer or Granting of Right from the Crown to the Subject-Statutes regulating Mussel FishingAppropriating and regulating Orders-Methods of Granting in Scotland, England, and Ireland . 76-92

Appendix A.-An Act for the Protection of Mussel Fisheries in Scotland [22nd July I847], 10 \& I I Vict.

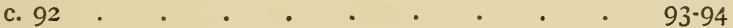

APpEndix B.-Excerpt from the Fishery Board for Scotland Regulations for the Instruction and Guidance of Persons applying for Fishery Orders 

MUSSEL BAIT-SUPPLY AND DEMAND

ALL who are interested in our sea-fisheries-one of our greatest national industries-must be aware that the question of the decrease of bait has now gained a position of importance amongst the pressing subjects of the day. Public shell-fish beds are threatened with extinction, through a long course of indiscriminate fishing under an improvident system. Oyster fisheries have been preserved in certain places, where private protection and regulation have been secured, while scalps free to all have become exterminated. The revival and systematic cultivation of the oyster is a project of great value to the country, but although this shell-fish is regarded directly as a food and a luxury, the benefit to be derived from its extensive cultivation is of much less importance than that which naturally results from an ample supply of 
mussel bait for hook-and-line fishing. White-fish fishing produces a vastly more valuable food than oyster culture; and without an adequate supply of bait, the craft of line-fishing in Scotland is paralysed, and the livelihood of our fishing population reduced. Poor fishing through lack of suitable bait, and the consequent destitution among fishers, have long been endured in silence. From time to time an indication of the evil may have come under the notice of a few; but not till the investigations of the Mussel and Bait Beds Commission in IS88 did the full significance of a baitless condition become evident. Since then, several attempts have been made to establish bait fisheries in a regulated form, but still at the present day, the old evil, like a dry-rot, spreads its insidious growth beneath our feet.

Sixty or seventy years ago the supply of mussel bait, in view of the small number of fishermen and the length of their lines, must have seemed inexhaustible. Now conditions are altered. The large boats worked by more men, at greater distances from the home ports, have increased the possibilities of line-fishing. The larger the crew, the longer does the line become, and the more is a copious supply of mussel bait needed. When 
the trawling industry was first established in the North Sea, the fish of the Dogger Banks and Silver Pits were regarded as capable of furnishing an inexhaustible supply, since they could collect from the vast area of unexplored sea-bottom reaching to the shores of the Netherlands and Norway and open to the endless Arctic. The fishermen of Grimsby and Lowestoft know now that the constant and much increased fishing has made an appalling difference on the supply of both flat and round fish. The fishermen of Scotland know, in the same way, that constant and unregulated fishing for mussels has brought about the present state of decay which we all deplore.

The evidence given before the Mussel Commission, by 162 individuals more or less directly interested in the supply of mussels, most clearly brought out the fact that there was a dearth of bait; showed indeed that the vast majority had suffered keenly from the high price necessarily paid for transported or imported shell-fish.

The fishermien on the coasts of Banffshire, Aberdeenshire, Kincardineshire, and Berwickshire especially have suffered in this way. Small or depleted beds existing in these counties supply 
first the strictly local need, and meet the requirements of neighbouring villages only when there remains a sufficient quantity. In this way, fishermen at a distance from beds are at a great disadvantage, and have usually to rely on the purchase of mussels sent to them by rail. Since the time when this practice became necessary, bait has been supplied from the estuaries of the Clyde and Tay, from Ireland, Holy Island, Boston, Lynn, and the Thames. At present, the scalps of the two Scotch estuaries, with a very considerable importation from Holland, form the chief supply of all fishermen who are not fortunate enough to have in their immediate neighbourhood some productive scalp.

The history of the French oyster industry should have taught us a lesson with regard to both our oysters and mussels. It has not done so in our care of the former shell-fish, but since our mussels take longer to exterminate, we have a longer time in which to change our present condition into one of regulated action.

France was at one time entirely without oysters, through precisely the same want of State regulation and supervision as we are now suffering from.

In studying the system now adopted with so 
much success in France, one cannot but be struck by the readiness with which, through the local commissaires of marine, the interests of individual culturists are protected and the terms of the State rentals suitably regulated. The Government wisely retains natural oyster-grounds for the production of seed with which beds all along the coast may be stocked. On these no dredging is allowed, except at such limited times as may be appointed. The beds are great reserves capable of being called out whenever there is the slightest danger of a national oyster decline. Above all, as I have previously had an opportunity of pointing out, ${ }^{1}$ France recognises the fact that a system of keeping shell-fish beds open for the benefit of the public must give way to the system of renting the sea-bottom and foreshores to such individuals as will cultivate the beds, and thus render them of increased value to the country. In other words, the system adopted with farms on dry land must be carried also to such parts of land as are covered by the sea, the Crown being landowner.

In backing up her position, France has further given lessees complete power of protection, and

1 Refort of Proceedings of Conference, I893, National Sea Fisheries' Protection Association, Fishmongers' Hall, p. 202. 
has established her shell-fish fisheries on such a sound, because thoroughly regulated, basis, that confidence in the success of shell-fish culture has been completely restored, while the industry has risen to a position of great national importance. In Scotland we have 43,000 people directly deriving a livelihood from sea-fishing, besides the army of workers who carry on the business of the fish trade on land. A few years ago there were 50,000 fishermen and boys. We have seen our public oyster fisheries slowly decline, and all but expire. We now are watching our mussel beds as they diminish in the same way.

It is not the purpose of this little book to advocate one particular line of action by which the results of years of neglect may be at once left behind by an advance towards an Elysium for the supply of endless fishing lines, but if we can show how the process of culture can be carried on with success and pecuniary gain, we shall help those who are at present struggling to build the foundations upon which we may at length erect a new fisherman's industry.

The scarcity of mussels, and the consequent increase in value now set upon mussel beds, can be clearly appreciated from a statement made by 
Mr. James Johnston of Montrose before the Mussel Commission. ${ }^{1}$

He says: 'It is a fact that the Ferryden fishermen were offered the sands of Dun at the beginning of the century at $£ 5$ per annum, and two dozen haddocks per week, and one cod-fish; but bait was so cheap at that time that the fishermen did not think it worth their while to accept the offer. These sands are now let to our firm for $£ 500$ a year.'

Fishery Bills have recently been introduced, containing most valuable clauses for the express purpose of bettering the mussel supply; but, from one reason or another, these have met with misfortune.

On account of the immense fertility of the mussel, however, we are still able to say that, on many of the beds left entirely without protection, a nucleus remains. With properly established conditions of regulation and development, we have still small centres of life which, if cultivated, could furnish an ample supply of this muchneeded bait.

It is true that while the lack of bait has been

1 Report of the Commitlee on the Condition of the Scottish Mussel and Bait Beds, 1889, p. 95. 
increasing, the industry has branched out into systems of procuring fish in which bait is unnecessary. The enormous increase of beamtrawling, for instance, has produced a stimulus amongst a different class of the fishing community, and has even opened up markets for certain fishes which are procured in but small numbers by means of baited lines. Still, the fact is significant, that frequently, in recent years, ressels commonly used for trawling have been fitted for use in line-fishing, and that large steam 'liners' ply all over the fishing areas of the North Sea. These vessels, in sailing as they do from fishing ports such as Grimsby, Yarmouth, Lowestoft, or Hull, where trawling has become the staple method of fishing, can procure their bait of various kinds from the trawlers, and do commonly work in conjunction with them.

In Scotland the case is different. The herring and the long-line fisheries are the staple sections of the industry. Trawling is practically in its infancy, and is retarded in its growth by regulations having for their express object the protection of the time-honoured method of linefishing.

Yet in spite of these regulations we find from 
the latest official reports ${ }^{1}$ that 'while the returns of the line-fishing exhibited the large decrease of 95,200 cwts. and $£ 53,200$, as compared with I 892 , those of the trawlers increased by 45,600 cwts. and $£ 27,500$ respectively.'

In I 893 there were 142 beam-trawlers at work in Scotland over against I 35 in I892, an increase of 7 .

It is impossible to separate line from net fishingboats, as both methods are employed by the same crews, but taking both together we find that in I 892 there were 13,679 boats ( 44 steamers), in I 893 there were 13,3 IO ( 38 steamers), showing a decrease of 369 boats for the year I 893 .

To arrive at a more intelligent estimate of the amount of bait required by the boats of Scotland, however, so far as we can do so from official returns, we have to give our attention to the length of lines set and to the quantity of bait landed.

Before doing so, it will be well for us to understand the importance of mussel bait as against any other.

Many baits are used. The clam or scallop is probably quite as attractive as the mussel,

1 Twelfth Annual Report of the Fishery Board for Scotland, I894, Part I. p. xi. 
but is much more local in its habitat, not generally to be found left uncovered by even the lowest tide, and never present in the brackish water of river-mouths where fishing harbours are commonly situated.

A bait probably superior to either mussel or clam is ink-fish (cephalopods). It is a rare and expensive bait, being procured almost exclusively by means of the beam-trawl. A box of ink-fish is sometimes sold for bait at as high a figure as from $£_{3}$ to $£ 4$. Half this price may be taken as prohibitive to such fishermen as are entirely dependent on their own resources.

Other common baits are lug-worm, herring, whelk, cockle, limpet, etc., but for the line fishermen of Scotland the mussel has advantages which secure for it the premier position. The extensive stretches of natural mussel grounds, the extreme suitability of environment and climate to the successful growth of the mollusc, the ease with which it can be procured and handled, coupled with its most excellent attractive qualities, place it at once as the most important of all baits. It has been in common use since time immemorial, and has lasted most wonderfully, considering the carelessness with which its growth has been re- 
garded. The outcry so loudly heard at the present day results from the total disregard of the good old maxim, 'Waste not, want not,' and if our fishermen could always get the mussels they require (and if there were as many fishermen), the statement made by the Mussel Commission in I 889 would still hold good, viz., that 'nearly all the 50,000 fishermen of Scotland use mussels as their bait during some part of the year; some do so during the whole year; the majority for all that portion of the year when they are not engaged at the herring fishing.'

Several attempts have been made to manufacture an artificial bait which will be cheap, and sufficiently effective to supply the much-felt need. Valuable information has been gained as to the particular senses brought into play by different fishes in hunting for their food, ${ }^{1}$ but the chemical experiments $^{2}$ based on this knowledge, though productive of many attractive substances, have failed, so far, to yield a suitable medium by means of which to convey the essences. Natural baits preserved by freezing, or in boracic acid, are used with some success in a few localities, but success

1 Baitson, Journ. Mar. Biol. Assoc, vol. i. No. 3.

2 Hughes, ibid. vol. ii. Nos. 2 and 3, pp. 91 and 220. 
in these directions is not sufficient to remove, to any appreciable extent, our present difficulties. The number of Scotch fishermen appears to be at present decreasing, but if we now turn to a study of the most recent returns ${ }^{1}$ as to fishing gear in use, we find that, taking lines alone, the length, exclusive of bush and buoy ropes, amounted in 1893 to $74,779,090$ yards, or to a little over 42,488 miles - a line which would encircle the world one and three-quarter times. We find at the same time that the length of hand-lines used is estimated at 2,100, I 30 yards. Deducting this, we still have the great total of $72,678,960$ yards of 'set line.'

To estimate the number of hooks on this length of line is a matter of some difficulty, since a considerable variation occurs in the arrangement and number used in different localities, and on hand-lines.

In the Eyemouth, Leith, and Anstruther districts, fishermen commonly use I 200 hooks on each line, while as we go north the number diminishes. At Montrose, for instance, I IOO is usual; at Fraserburgh, 800 ; at Findhorn, 600 ; at Nairn, 500 are

1 Twelfth Anmial Report of the Fishery Board for Scotland, I894, Part I. Appendix A, No. I, p. 6. 
used. I regret that I have no data as to the number used in Orkney or Shetland. All along the coast, for many years, fishermen appear to have had a tendency to increase the number. If we take an average of 775 hooks (from 500, 600, 800 , and 1200), and estimate a line as 1200 yards in length, we get a total of $46,937,875$ hooks to be baited every time the total number of lines are used. This figure may perhaps be taken as a rough guide, which probably errs considerably as an under-statement of the number.

We have no data to guide us in any attempt we might make to estimate the number of times these lines were set in any year. We know that on an average two mussels are used to bait one hook, and we can see that if it were possible for us to multiply out an exact total of individual mussels used, the result would be a figure which, like the distance to the moon, could not readily be comprehended by the intelligence of man.

Taking the official returns of the Board of Trade, Fisheries Department, we are unfortunately unable to estimate the quantity of mussels landed annually on, or exported from, the coasts of England and Wales, since the figures are massed, 
after the columns referring to crabs, lobsters, and oysters, under the title, 'other shell-fish.'

Irish returns are furnished in the same manner. From the monthly returns supplied by the Scotch Fishery Board, however, I am able to reproduce the following table, showing the quantity and value of mussels landed in Scotland during the last four years.

It will be observed that there is a marked drop both in quantity and value in the columns for I 893, but it must be recollected that the number of boats and men employed is less.

\begin{tabular}{|c|c|c|c|c|c|c|c|}
\hline 1890. & 1891. & 1892. & 1893. & 1890. & 1891. & 1892. & 1893. \\
\hline \multicolumn{4}{|c|}{ Quantity. * } & \multicolumn{4}{|c|}{ Value. $†$} \\
\hline $\begin{array}{l}\text { Cwts. } \\
\text { I } 77,328\end{array}$ & $\begin{array}{l}\text { Cwts. } \\
23 \mathrm{I}, 063\end{array}$ & $\begin{array}{c}\text { Cwts. } \\
247,4 \text { I I }\end{array}$ & $\begin{array}{c}\text { Cwts. } \\
239,958\end{array}$ & $\underset{10,930}{£}$ & $\underset{14,329}{£}$ & $\underset{14,534}{£}$ & $\underset{13,240}{£}$ \\
\hline
\end{tabular}

Note. - The S. F. B. 1894 Report gives the quantity for 1892 as 247,189 , for 1893 as $239,746 \frac{1}{2}$.

* The quantities refer only to Mussels landed from native waters.

† The values are calculated from the 'landing prices.'

In view of other evidence, it is unfortunately not possible to console ourselves with the belief that the recent falling off in the quantity of mussels landed is the result of fewer being required. 
A most significant statement is made in the current Report of the Scottish Fishery Board, ${ }^{1}$ as follows: 'It is interesting to note that the quantity of fresh fish imported into Scottish ports last year was i 8,000 cwt., valued at $£ 5000$. The bulk of this return consisted of shell-fish, of which 14,500 civts., valued at about $£ 4000$, were imported. Mussels contributed principally to these figures, these molluscs being brought over from Holland for use as bait by the line-fishermen. Nearly 2400 cwts. of herrings, valued at $£ 600$, were also imported, principally from Norway, being brought over in ice, and used as bait. As compared with the preceding year, the quantity of mussels imported decreased to the extent of 20,800 civts., and the value by $£ 2300$.'

The value per civt. of Holland mussels is about 5s. 6d. This is a large figure when compared to the average price of Is. Id. paid for native mussels, and is prohibitive to many fishermen dependent on their own resources. The fact that it is necessary to import a mollusc which grows naturally in great abundance on our own shores is in itself significant of the condition of our bait beds. IVe

1 Twelfth Annual Report of the Fishery Board for Scotland, I894, Part I. p. xvi. 
must also note the decline both at home and from abroad. In 1892 there was a decrease in the number of net and line fishermen by 317 (92 boats). In I 893 we are told the decrease in the amount of bait from abroad is 20,800 cwts., from native sources $7453 \mathrm{cwts}$. (Board of Trade returns), making a total of 28,253 cwts., or I 4 I 2 tons I 3 civts. Looking at these figures from the opposite point of view, so as to arrive at the total quantity of mussels landed from all recorded sources, and taking the figure of 14,500 cwts. of shell-fish given in the quotation from the Fishery Board Report as I2,000 cwts. of mussels-on account of the statement that 'mussels contributed principally to these figures'-we find that in I 893 there were $24 \mathrm{I}, 158$ cwts., or 12,057 tons, and in 1892 the much larger total of 279,986 cwts., or practically 14,000 tons (13,999), a decrease in the recorded supply for I 893 of 2000 tons of mussels. This is a noteworthy falling off, coupled as it is with a corresponding rise in money-value.

It is perhaps unfortunate, that in official returns of weights of fish some system of indicating the relation between the hundredweight (the standard usually employed) and the number of fish or shellfish it contains is not given. As in the important 
inquiries recently conducted as to the numbers of immature flat fish captured off our coasts, figures in cwts. gave no indication as to whether there were a large number of very small, or a much less number of medium-sized or large fish; so is it in the case of mussels. Figures of cwts. of mussels landed give no estimate of the enormous quantities of small and useless mussels which are taken along with those of serviceable size, and which go to swell the total weight; nor do we learn if the higher price of the Holland shell-fish bears any relation to a greater size, though this is probably the case.

From another part of the Fishery Board Report already referred to we find that two-fifths of all the mussels taken in Scotland come from the beds off Greenock and Port-Glasgow, and that the beds in the Firths of Tay and Forth are accountable for nearly all the remainder. The quantity taken in the Clyde in I893 amounted to 96,000 civts.

Further, the amount of fish caught by hook and line has fallen, from the total for 1892, by 95,200 cwts. and $£ 53,200$, and there has been an enormous increase, in proportion, of net and trawl caught fish. This most serious decrease 
should be noted, since without some improvement in the bait market it is likely to become more and more obvious. Fishermen with whom the tide of ill-fortune has set in-and there are few who have not experienced this of late-can ill afford to spend money on bait which has been brought, at considerable expense, from Holland or Ireland.

If the home crops of mussels continue to decline, and prices to rise, this great branch of the industry must slowly be abandoned for the already overstocked net fishing, and the capital sunk in the 42,000 miles of Scotch fishing-lines sacrificed. 


\section{CHAPTER II}

\section{PAST AND PRESENT MUSSEL BEDS OF SCOTLAND}

I HAVE thought it desirable to attempt the somewhat difficult task of describing shortly the principal mussel beds of Scotland.

A general idea can in this way be obtained as to the number and extent of our scalps, while the notes given in each case may help the reader to estimate the present condition and past history as well as, in some cases, the possibilities of local bait supply.

The order in which the beds are described is from the southern part of the East Coast, round the north of the country to the southern part of the West Coast.

Not a few of the beds have been visited by me in the course of scientific fishery expeditions when in the service of the Fishery Board for Scotland, and at other times; but I have relied 
principally upon such authentic statements as are at my command.

Tyninghan Sands, Dunbar.-These beds, which are about three-quarters of a mile long, have been in an entirely exhausted condition for many years. Formerly they supplied bait to the fishermen of both Dunbar and North Berwick. There seems to be some doubt as to the existence of an old charter granting possession of the beds to an Earl of Haddington. The beds are entirely unprotected.

Patches of mussels occur in the neighbourhood of Berwick and at Rattray Head, but they are insignificant compared with the beds across the border on Holy Island and Warren Sands. The latter places, however, have now shared the fate of the Tyningham Sands.

Musselburgh BeDs.-At the mouth of the river Esk extensive beds are believed to have existed at one time. The name of the present town seems to owe its origin to this fact. The various mills erected on the river produced such a pollution of the water that the mussels were destroyed. Patches still exist near Portobello and the Black Rocks. The water of the Esk is being purified. 
LEITH BED.-This bed, situated to the west of Leith Pier, is the property of the city of Edinburgh, and is leased to the Newhaven Society of Free Fishermen. It has an estimated area of about 550 acres, and partly dries at low-water springs. The yield from this bed seems to continue fair, although no special efforts are made to cultivate it. The sewage of Leith is believed to be most beneficial. Mussels from this bed are sold at Is. a basket.

Granton Bed lies to the west of the harbour, towards Cramond Island, and is the property of the Duke of Buccleuch. Its extent is apparently not very clearly known, because the bed has been formed naturally, and the ground is not worked over. This bed seems to be a curious example of mussels naturally asserting themselves on ground protected in order to grow oysters, the supply of oysters having failed. Mr. John Anderson, Edinburgh, was tenant of oyster fisheries in I884, and did at that time sell off the mussels which appeared. Since this time, however, a more or less regular bed seems to have become established, although in reality no mussels are supposed to exist. Fishermen are not allowed to dredge mussels on this otherwise unused ground. 
CRAMONd IsLand Beds.-These beds, which are known to have been of great extent round the mouth of the river Almond, have met exactly the same fate as the Musselburgh beds. Patches still occur to the west side of the river mouth.

A bed in the neighbourhood of BURNTISLAND has also vanished.

Another private bed in this locality is that of ABERDOUR, granted to the Earl of Morton by the Board of Trade in I870-the same year as the Duke of Buccleuch's bed mentioned above. The grant, in this case, is for a mussel fishery.

The Eden Beds, St. Andrews.-The scalps situated in this most suitable estuary are of wide extent. The most important beds are those of the south shore, owned and worked by the Corporation of St. Andrews. The quality of the Eden mussel is much esteemed. The ground is naturally firm, and is overspread by the fine silt of the river. This silt affords rich feeding, but has now accumulated to such an extent that many of the beds are too high to render the best results, being exposed too long by the falling tide. The fishermen of St. Andrews have the legal right to be supplied with bait from these beds. The price averages about Is. per basket, exclusive of cartage. 
On the best parts of the scalps the growth may be said to be rapid, but the fishermen have repeatedly complained of the size of the shell-fish, and evidence is not wanting to show that mussels on the highest parts remain for about seven years before they are considered of suitable size for bait. The Corporation appears to reap an annual profit from the bed of from $£ \mathrm{I} 00$ to $£ 500$. The city is entered on the valuation roll for $£ 290$, I4s. The mussels are transplanted and cropped in rotation, so far as this is possible on account of the diversity of locality.

THE TAY BEDS.-These consist of extensive beds in the channel, the property of the Crown; and beds on the marginal flats, those in the vicinity of Broughty-Ferry being claimed by Admiral Maitland Dougall. No cultivation or regulation is attempted, but the beds are vast, and have been estimated to produce as much as 3000 tons annually, giving employment to a large number of mussel dredgers. About eighty East Coast fishing ports are said to get their mussels from the Tay.

The Ladyband Bed, Monifieth.-This bed is about three-quarters of a mile in extent, and lies outside the channel of the Monifieth river. 
It is situated on the property of Lord Dalhousie, but no authority seems ever to have claimed right of possession. In consequence, the bed is of little value, and has been much destroyed both by over-fishing and by the inroads of star-fish.

The Montrose Beds.-These beds are the best regulated and managed in the country. The district return for 1893 is given as 43,095 cwts. The Rossie beds extend to about 45 acres, as much as 23,000 measures, about 950 tons, having been taken from them in one year. This amount was however found to be excessive. At the time of the Commission the bed was yielding between 500 and 600 tons annually. The grounds now under cultivation were at one time all but destitute of mussels, but by the exertions of the Ferryden and Usan Society of Fishermen, led by Mr. James Johnston, 'seed' was collected and bedded, and the system of cultivation adopted which has since yielded such excellent results. The measure of mussels as used at Montrose is from 90 to 96 lbs. in weight.

The village of Ferryden is on the south bank of the river Southesk, on the estate of Rossie. The beds are the property of Messrs. James Johnston and Sons, Montrose, and are leased to 
the Ferryden Fishermen's Society. 'They are closed each year from the beginning of July to the end of November, but mussels can then be had from the beds on the Dun Sands, on the north side of the river. These grounds are leased by Messrs. Johnston, and are between 70 and 80 acres in extent.

The Ythan Beds, Aberdeen, are the property of Undy of Undy, and are let on lease. The beds are very irregular, some parts being a considerable height above low-water mark. Transplanting is carried on, and the beds are scoured to a certain extent. Fishermen lift their own mussels, and have also to assist in transplanting. Collieston, Newburgh, and Old Castle fishermen are supplied first of all, and there are seldom any shell-fish available for men from a greater distance. The annual crop is estimated as being only about 300 tons.

THE FINDHORN BEDS are the property of Mr. Munro Ferguson of Novar, and are let on lease. The yield of the Findhorn district in I 893 is officially stated to have been 2255 cwts., showing a decrease of 2237 cwts. on a larger return for 1892 . The Findhorn river beds are limited in extent, and the crop fluctuates con- 
siderably, the floods of the river Findhorn occasionally altering the ground. Seed-mussels are collected from two natural beds near the mouth of the river, and are transplanted to a position above the town, where they are protected. All three beds may be said to be quite uncovered at low tide. The mussels of these beds grow to a large size, and are preferred to any others by the fishermen of the Moray Firth.

In former years two other mussel beds existed in this locality, one on each side of the mouth of the river. They are believed to have been partly fished out and partly destroyed by shifting sands, which are common on this coast.

THE NAIRN BED.-This bed is of special interest, since it is the direct product of mussel culture in recent years. After the sitting of the Mussel Commission at Elgin, in October I888, the fishermen of Nairn resolved to experiment with mussels on their own account. They had no mussels of any value in their immediate neighbourhood, and were dependent mainly on those brought from the Clyde. In the belief that in former days a bed existed in an outlet locally termed E'e, six miles from Nairn, at the old mouth of Findhorn, the fishermen with most commendable 
enterprise resolved to attempt the commencement of a new bed in this locality, although they were aware that shifting sands did exist. Accordingly, small mussels growing upon the exposed rocks in the vicinity of Nairn were collected, and on the I6th April I889 were transferred to E'e.

It was found that in a few days they had bound themselves into clusters, and were forming a tolerably firm mass on the top of the loose sand. Very little fresh water enters the sea in the neighbourhood, but the effect of transplanting was such that in eleven months it was declared that the once small and stunted mussels were of the size most suitable for bait, i.e. two to a hook. On 23rd January I89I, therefore, a large number were lifted and carried to the pier-head at Nairn, where they were sold for the large price of $2 \mathrm{~s} .4 \mathrm{~d}$. per quarter cran basket.

Subsequently five tons of mussel seed were obtained, through the kindness of Mr. Hogarth, lessee of the Findhorn beds, and planted in the same manner as before. These mussels also grew admirably; and early in the summer of 1893 , having been transplanted for one year, they spawned. A very decided hope, therefore, may be entertained that a permanent bed has been established. 
The Inverness and Beauly Firth Beds.The story concerning the beds in this district is decidedly sad. In this large area, where numerous mussel beds, favoured by excellent natural advantages, exist, the shell-fish have been wantonly squandered and the beds left barren. The fishermen of the locality seem to be alone responsible for this condition, no bed being safe from their constant depredations.

The Corporation of Inverness, in I883, ceased leasing the town beds, and took up the care of their own mussels, giving attention more especially to those on the shore between the mouth of the Caledonian Canal and Kessock Ferry. The result seems to be uncertain, and the opinion of the Mussel Commission was that sufficient care had not been given to the matter.

The Munlochy beds are claimed by the Avoch fishermen, and, like similar beds in the Cromarty Firth, are fished out and left to nature.

The Redcastle beds are leased from the Crown, ${ }^{1}$ but are rendered of little value through poaching.

The beds in the upper reaches of Beauly Firth, owned by Lord Lovat, are reduced by the same cause.

1 Mussel Commission Report, loc, cit., p. xiii. 
This whole district, as well as that of Cromarty, requires a thorough system of protection against raiding, as well as careful culture, to restore the old condition of the many splendid beds.

Cromarty Firth Beds.-There are several beds in the firth, viz. :-Nigg Bay, Udale Bay, Invergordon, and Novar. The scalps in Nigg Bay are most extensive, having been estimated to cover I 895 acres. The ground is firm and admirably adapted for carrying an immense quantity of mussels. The beds dry at low tide. Both Nigg and Udale Bays are almost destitute of mussels, through the indiscriminate lifting of mussels.

In former days (before I859) these beds were protected and the shell-fish cultivated to a certain extent. They were leased from, or worked by, the Dukes of Sutherland, and yielded good quantities of shell-fish. The practice of protection fell into abeyance, however, and the fishermen of Cromarty eventually attempted to claim them as their exclusive right. The important dispute of The Duchess of Sutherland v. Watson, etc., Ioth January i 868 , resulted, to which reference will be found in Chapter V. p. 8o. Even at the present day fishermen from other places are prevented from gathering mussels, while the Cromarty men 
themselves do nothing to improve the stock. It should be remembered that Cromarty was at one time (when the mussels suffered most severely) a thriving fishing village, and mustered a far greater fleet of boats than it does at present.

The Dornoch Firth Beds.-The principal beds are situated opposite the town of Tain, and are held by the town, under the charter of Charles II. (I67I). They are supposed to cover an area of about 9 acres, but have never been surveyed. The inshore scalps are becoming high through the accumulation of mud over the hard sandy bottom.

The yield of these beds is now far short of the former supply, and cultivation has been practised only within recent years. The scalps at one time were much over-fished, and since some, as the Black Scalp, are much exposed to danger from easterly gales, considerable destruction has resulted. Sales are made chiefly to fishermen from a distance.

At the village of Inver, east of Tain, there are a few small beds used by the local fishermen.

The Torlogie Beds lie to the west of Tain, on the southern shore of the firth. Cultivation has been practised here by the lessee, but the 
scalps have been considerably poached, and are subject to deposition of shifting sand, and to heavy gales.

The Skibo Beds (Meikle Ferry) are on the north side of the firth, opposite Torlogie. They are about $\mathrm{I} 3$ acres in extent, and are always covered by water. The yield has ever been variable, the ground being very subject to shifting sand and to the inroads of star-fish. No cultivation is considered possible; poaching is common; and the dredges which are in use appear to increase the destruction by aggravating the shifting of loose sand. The beds are leased from the Skibo estates.

Loch Fleet Beds (Little Ferry).-These beds are the property of the Duke of Sutherland, and are cultivated at considerable expense. They are mostly uncovered at low tide. The ground consists of sand and shingle, and the mussels are gathered chiefly by raking. The demand is greater than the supply. The beds are said to be growing too high, but, so far as I know, no scouring is practised.

ORKNey AND Shetland.-The line-fishing amongst these islands is confined very largely to the local boats, the herring fishing being the particular section of the industry which is most 
attractive to 'foreigners.' The local supply can easily be met by the native shell-fish beds, and by the use of worm and herring bait.

Since Iceland has prohibited the selling of bait to boats from the south, in order that the large whelks which are mostly used may be preserved for Icelanders, the custom has sprung up for Scotch and French boats to pick up mussel bait at the Shetlands, on their way north. Considerable beds have in this way become known to fishermen. The boats visiting the Shetland scalps load mussels for several days, packing them in salt or ice brought for the purpose.

LOch ROAG BeD, LEwis.-These beds, which are now in a rather exhausted coudition, are situated on the west of the island of Lewis. About thirty years ago they are said to have been most rich in their supply of mussels, and to have attracted boats from the north and east of the mainland. They were entirely unprotected, and most ruthlessly over-fished. Mr. Anderson Smith, who knows the beds, has described the manner in which both large and small mussels were taken, those not suitable for bait being thrown away. ${ }^{1}$

1 Report on Scottish Mussel and Bait Beds, I889, p. I4I. 
In the SKYE DISTRICT line-fishing is not practised to any great extent. A few East Coast boats with long lines visit the Inner Hebrides during the winter months for the conger, cod, and ling fishing. The numerous lochs, with natural scalps around the mouths of streams and rivers, supply a ready bait, and are free to all. They need not be mentioned in detail. The only case in which right of private fishing has been granted is that of the Greshernish oyster and mussel fishery. This order was confirmed in $187 \mathrm{I}$, being granted by the Board of Trade to John Robertson, Esq.

In the vicinity of OBAN, where, during the winter months, fishing by means of hook and line is now practised by a few East Coast boats, as in Skye, and also by local fishermen, mussel bait can be procured from several lochs. Natural beds of small extent exist in several of the lochs in the island of Mull, and in Loch Etive, Loch Creran, and Loch Feochan (principally at its mouth). Farther south also, Loch Melfort, Loch Killisport, and Loch Swin possess mussel scalps.

An order for an oyster and mussel fishery in Loch Creran was granted last year (1893) to Mrs. Ogilvie. 
WEST LOCH TARBERT contains an extensive mussel bed, but the loch is used for purposes of oyster culture, and Messrs. Hay and Co., who have the right of 'several fishery,' naturally do not encourage the growth of mussels in the immediate vicinity of their oyster beds. The mussel scalps, however, are more extensive farther down the loch than in the vicinity of the oyster fishery. Messrs. Hay and Co.'s order was granted by the Fishery Board in I888. It is for an oyster and mussel fishery.

The Clyde Estuary, with its ramifying lochs, contains many places where natural mussel beds exist. Campbeltown Loch was at one time the site of a fine mussel bed. The town common at the head of the loch was formerly known as the 'Mussel Ebb,' having at one time been part of the loch. Refuse from the town is said to have injured other beds in the loch. The Dhoirlinn scalp at Davaar is now also declining. Other beds of the estuary are at Ardrishaig, Inveraray, Lochriddon, Holy Loch, and Loch Long. In all these localities, and in the numerous bays and creeks where less important beds exist, there is no system of protection regularly carried on, nor is the export of mussels to fishing centres attempted. 
Line fishermen in this section of the Clyde estuary are few in number, their demands are easily supplied, and the beds are left to take care of themselves. Formerly, Holy Loch was, to the writer's knowledge, occasionally visited by boats taking cargoes of mussels, as described below in the case of the Gare Loch, but no trade in mussels for bait is systematically attempted from any but the Greenock beds, which, with one or two of the beds on the south or lowland side of the firth, are mentioned separately. The Gare Loch beds sufficiently represent the beds on the north side, where each loch, having a stream with a greater or less delta and expanse of alluvial deposit, forms at its upper end a natural mussel bed. In I869 an attempt was made in Holy Loch to establish an oyster bed. After considerable misfortune, the effort was abandoned; but a private right of oyster fishery was granted at that time to James Hunter, Esq. of Hafton.

The GARE LOCH Beds (Clyde).-There are two beds in this locality, one at the head of the loch, and another at the 'jabble,' where the entrance to the loch is narrowed by a gravel spit running out from the Row shore. The latter is all but exhausted, but the former, although it has 
never been protected, and has been much fished, still retains a considerable quantity of mussels. This bed is an extensive one, and capable of great development. East Coast fishing-boats, coming or going from or to the IVest Coast, or the Irish fishing, by the Forth and Clyde Canal, have for many years been in the habit of lifting cargoes of mussels from Garelochhead, but, in common with other beds of the Clyde estuary, the mussels have also been extensively gathered by women from Glasgow, who sell them for food in the poorer quarters of that city.

GreEnock Beds.- These are the most extensive beds in the country, the return for 1893 showing a landing of 95,910 civts., valued at $£ 3352$. They are claimed by the Corporation of Greenock, under a clause in a charter of George III., but are freely fished by all dredgers of the neighbourhood. It was stated before the Mussel Commission (I889) 'that during the last fifty years, over I00,000 tons of mussels have been taken from the scalps,' half that amount being lifted by means of rakes and dredges from portions of the scalp constantly covered by water.

From a table submitted by Mr. J. M'Laughlan, mussel merchant of Port-Glasgow, it appears that 
from the year I878 to I888 no crop was produced as great as that recorded for 1893 in the Fishery Board's Report-the I 886 crop, the last mentioned, being 3906 tons, i.e. 889 tons less.

In explanation of this, however, it has been said that a few years ago a serious decline set in, so that the merchants and fishermen had to seek 'seed' from West Highland lochs and from Ireland. The result, coupled with more careful attention, appears to be the figure of $1893,-95,910$ cwts.

Ballantrae Beds.-The chief bed in this locality is Creetown Scalp. In I893, mussels were fished mostly by Morecambe Bay men. 2380 civts. were landed, and mostly sent to England. ${ }^{1}$

IRVINE RIVER BED.-This bed was looked upon, in former years, as one of the most valuable in the south-west of Scotland. It has unfortunately been all but exterminated by the pollution of the river by the chemical and other works of the town of Irvine. The bed is about a mile long, is composed of hard sand and muddy gravel, and is admirably adapted for growing mussels. It is largely uncovered at low water. The ownership

1 Twelfth Annual Report of the Fishery Board for Scotland, 1894, Part I. p. 202. 
is divided, the larger part belonging to the Earl of Eglinton, the remainder to the burgh of Irvine.

Several points of interest are raised from a study of the various beds enumerated.

It may be noted that there are great stretches of coast where no mussel beds of special value exist, but where important fishing centres are situated. Between the Ythan beds, just north of Aberdeen, for instance, and the river Findhorn in the Moray Firth, there are no mussel beds which, to my knowledge, can be regarded as of any importance, if indeed there are any true beds at all. But in this stretch of coast the towns of Peterhead, Fraserburgh, Macduff, Banff, Buckie, Portsoy, Lossiemouth, and Burghead occur, all important from a fishing point of view, and all provided with railway communication. Line-fishermen in this part of Scotland are entirely dependent on the transportation of mussels, being supplied very largely from the Clyde scalps at Greenock.

The Ythan beds, we have seen, do not as a rule supply more than a purely local demand, yet south of this, by Aberdeen and Stonehaven, there are no beds worth mentioning till we reach Montrose. 
The group of beds in the Moray Firth are much reduced by reckless fishing, and now cannot supply the needs of the purely local fishermen. This scarcity aggravates the poaching disposition, so common in the north, and frequently turns the procuring of mussel bait into an hereditary strife amongst fishermen of neighbouring villages. Men here are frequently reduced to such poor bait as limpets.

If the vast extent of scalps situated in the Inverness and Cromarty Firths alone were properly protected and cultivated, nuclear areas would be formed which could provide a supply of seed for all the other scalps in the Moray Firth, besides forming a greatly increased stock of bait for fishermen far and near. 


\section{H A P T E R II I}

THE NATURAL HISTORY OF THE MUSSEL, AND THE TREATMENT OF BAIT SCALPS.

A KNOWLEDGE of the structure and life-history of the mussel is necessary before the practice of mussel culture can be carried on to the best advantage.

Such points as the following should especially be attended to :-

(a) The conditions most favourable to the growth and increase of the mussel.

(b) Conditions adverse to growth and increase.

(c) The time and the manner of spawning.

(d) The rate and variations of growth under certain conditions.

After a treatment of these points, the more practical questions of the cropping of beds and 
NATURAL HISTORY OF THE MUSEL 4I the influences which affect the crops will be taken up.

[Those who desire a more detailed and scientific treatise on the morphology or embryology of the mussel than can be entered upon here, may be referred to the following :-

Sabatier. Anatomie de la Moule Commune (Ann. des Sci. Nat., $\mathrm{vi}^{\mathrm{e}}$ Série, 1877$)$.

Lacaze-Duthiers. Organes Génitaux des Acéphales Lamellibranches (Ann. des Sci. Nat., IV ${ }^{\mathrm{e}}$ Série, I 854 , t. ii.).

Wilson. On the Development of the Common Mussel (5th Ann. Rep. Fish. Board, Scot. I887, App. F, p. 247).

Purdie. The Anatomy of the Common Mussels (Mytilus latus, edulis, and magellanicus). Studies in Biology for New Zealand Students, Museum and Survey Department, Wellington, I887.]

The common mussel, along with the oyster, cockle, clam, and other well-known bi-valve shellfishes, is included in the classification of the group Mollusca, under the class Lamellibranchiata.

The two shells (or what is more properly described as a right- and left-valved shell, connected by a ligament), the large gills, the absence of any well-defined head, and the presence of a bi-lobed mantle, are their distinguishing features.

The shell is secreted by the outer surface of the mantle. The 'foot', so well marked in the cockle and scallop, and absent in the oyster, is not of great size in the mussel, and has the 
peculiarity of possessing a byssus gland which secretes the 'beard' for the attachment of the mollusc.

On opening a mussel and folding back the shells, the body is seen to consist roughly of the two flaps of the mantle attached to, and filling, the two valves of the shell, and a more or less compact portion in the centre. The thin or tapering end is described as anterior, the thick and more bulging end behind the hinge as posterior. The mouth is at the anterior end, and between the mouth and the beard is the foot, the shape of which varies very much according to the extent to which it is protruded or retracted.

Just inside the edge of the mantle, at the anterior end, will be found two pairs of small loose flaps, an outer and an inner, on each side of the middle line. These are termed the labial palps, and the exact position of the mouth may at once be determined by examining their anterior ends.

Extending from between the inner and outer palps, on each side, to the posterior end of the animal, the gills may be distinguished; a pair on each side of the middle line. Each pair, when the mussel is in its normal position, projects freely in the cavity formed by the surround- 
NATURAL HISTORY OF THE MUSSEL 43 ing mantle, being thus in the direct stream of water passing along from the anterior to the posterior end of the animal. If cut across, each pair would be seen to be arranged in the form of a narrow $\mathbf{W}$, the central part of the letter being the point of attachment, the outer and inner arms (ascending lamellæ) being free at their upper ends. At the inner side of the point of attachment, or central part of the $\mathbf{W}$, near the hinder end of the body proper of the mussel, on each side, is the genital papilla, where the eggs or sperms escape, and immediately behind this again is the opening from the kidneys. Just behind the muscle which closes the hinder part of the shell the anus is situated, the rectum or last part of the intestine being usually seen against the light-coloured (posterior adductor) muscle.

The digestive tract, from the mouth to the anus, runs along what may be described as the upper part of the shell below the hinge. The gullet, which is simple, opens into an ovalshaped stomach, the detailed arrangements of which have given rise to some discussion among zoologists, into which we need not here enter. From the posterior end of the stomach the intestine passes backwards in a straight line as far 
as the posterior adductor muscle, where it curves back upon itself, and returns in a somewhat oblique manner to the left side of the stomach, from which situation it finally passes back to the anus.

In Sabatier's description, the straight backward portion, which I have described as the first part of the intestine, is included as part of the stomach (called the tubular stomach).

The heart, consisting of a central ventricle and two lateral auricles, is situated in a thin walled cavity of its own, rather behind the middle point in the line along the back of the mussel. A wonderfully complete system of arteries and veins, beautifully demonstrated by Sabatier, supply the various organs.

Two kidneys, or, as they are commonly called in shell-fishes, the organ of Bojanus, are found on the lower side of the body, one passing on each side of the foot, brownish in colour, having openings, as already noted, immediately behind the genital papillæ. Two internal openings also communicate with the cavity in which the heart is situated, and in this way the organ has a more powerful action in aerating the blood.

The nervous system shows three centres of 
stimuli (paired ganglia), all connected to one another, and giving off branches to the various organs in proximity. One centre of stimulus is situated in what may be called the head region, another in the foot, while the third supplies the digestive and reproductive organs, the gills, and part of the mantle; fusing in this last organ, with branches from the head ganglia.

Lastly, we have the reproductive organ, the greater part of which is situated in the substance of the mantle. The remainder, which is most readily seen when the mussels are in a spawning condition, is situated on the sides of the centre or body proper, i.e. where the lobes of the mantle pass off from the central body. A number of ducts in each mantle-lobe collect the genital products into a common tube at a point close to the anterior end of the cavity of the heart, below the retractor muscles of the foot. From this point the ducts pass inwards, till they open at the genital papillæ towards the hinder end of the central body, at the inner angle of the attachment of the gills, represented in section by the central apex of the letter $\mathbf{W}$.

The sexes of the mussel are distinct, although the arrangement of the male and female organs is 
alike. Towards the spawning season the sex of a mussel can be told at a glance, without much difficulty, by a difference of colour which usually appears. The male exhibits a whitish or reddish yellow, while the female is a deep red or orangered colour. The genital duct can frequently be traced crossing the brown-coloured organ of Bojanus.

Sabatier seems to have studied the mussel when the reproductive organs were inactive, but LacazeDuthiers notices the difference of colour, as also does Purdie in the New Zealand mussel, while Wilson ${ }^{1}$ states that, after a close inspection, it will be noticed that the sperm sacs are mostly arranged 'in more prominent groups than the ovigerous masses.' This author also describes the genital products as follows:-The male sperms or spermatozoa 'have a balloon-shaped head tapering continuously off to a fine tail.' When taken in the perfectly ripe condition, by cutting open the mantle of the parent they form a creamy fluid. If the sperms, when highly magnified, are entirely free from one another, and active in their movements, they are perfectly ripe. If on the other

I Fourth Annual Report of the Fishery Board for Scotland, Appendix F, I886, p. 219. 
NATURAL HISTORY OF THE MUSSEL 47

hand they are seen to be attached to each other in bundles, and the appearance of the fluid to be only slightly milky, the sperms are not quite ready for shedding.

When a ripe female is opened and the mantle cut into, the fluid which emerges is orangecoloured. Each egg is circular in outline, when viewed under the microscope, and exhibits an opaque granular encircling membrane. By transmitted light, it has a slightly brown or greenish brown tinge. It is so small as to be barely visible to the naked eye. Surrounding the egg is a comparatively deep, transparent layer or envelope, which appears to facilitate the process of impregnation by retaining the sperms which may come in contact with it. It probably also protects the egg to a certain extent, but is present only in the very early condition, about the time of fertilisation.

In the case of the oyster the eggs are retained in the mantle cavity for a considerable time after fertilisation has taken place in the parent. The eggs are then termed white spat. Oysters being hermaphrodite, however, may perform the functions of one or other sex at different seasons.

In the case of the mussel this is not so; the 
sexes are perfectly distinct, as we have already seen, and impregnation takes place as the eggs, expelled from the parent, float freely in the water.

In Scotland, owing to the tricks of a fickle climate, the season at which this spatting takes place is subject to considerable variation. The genital glands show signs of activity and enlargement during the winter months, and all mussels which are likely to spawn may probably be considered as ripe at the end of April. By this it must not be understood that mussels do not spawn before April ; the statement refers purely to the common condition. Many beds may, during warm spring weather, have thrown off great quantities of spat before then. Professor M'Intosh tells us, for instance, ${ }^{1}$ that in January the reproductive organs are well developed, 'and by the beginning of February ripe eggs and sperms are common' within the mussel. Ripening depends largely on a steady continuance of genial weather, and if this is not vouchsafed, the spatting season is much interfered with. Hence it happens that spatting occurs at very different times in different localities.

1 Report on the Mussel and Cockle Beds in the Estuaries of the Tees, the Esk, and the Humber. Hull, IS91, p. 27. 
We may, however, expect spawning to take place generally after April, and to be most abundant in June. At the same time it must be remembered that a late summer commonly prolongs spawning through July, and that spat has frequently been observed in the early part of August. Spawning, once commenced, is much influenced by weather. Favourable conditions may extend the time, so that the various individuals of a bed get rid of their full complement of eggs and sperms, a 'heavy fall of spat' being the result; or, the season may be brought to a sudden termination, and the embryos already in process of development much injured by the sudden advent of cold weather and storms. The opinion that intense heat is detrimental to the spawning capabilities of mussels is held in some quarters of France; but the highest temperature of our summers can only, I think, be considered as advantageous, unless the scalps are left uncovered by the tide for long periods. The same influences also determine the rapidity with which the spat becomes finally fixed.

From observations made at St. Andrews by Professor M'Intosh, and reported by him to the NorthEastern Sea Fisheries Committee, we are able to 
gain more information as to the time the freeswimming embryos become finally attached than from any other source. For several years Professor $M$ 'Intosh has observed the embryos settling first of all in the beginning of June on the small bushy zoophytes which grow on the shells of mussels on the Eden beds. On the buoys and ropes of the local salmon stake-nets also, minute mussels can generally be found in the middle of June. They are described as follows : $1-$

'They appear like grains of millet seed on the zoophytes, and measure from $\frac{1}{71}$ to $\frac{1}{21}$ inch in length, this variation corresponding to a difference in the stage of development.'

A few lines further on he adds: "The fry can detach themselves at will, and if the water in which they are confined be impure, they become restless, and, soon forsaking the zoophyte, swim to the side of the vessel, where they swarm at the water-line.'

Towards the end of September they measure an eighth of an inch. Professor M'Intosh also states that 'the salmon fishermen notice that ropes must be submerged a month, i.e. till about

1 M'Intosh, Report on the Mussel and Cockle Beds in the Estuaries of the Tees, the Esk, and the Humber, I891, p. 30. 
NATURAL HISTORY OF THE MUSEL 5 I the middle of June, before a deposit of minute mussels is observed.'

A detailed description of the embryo mussels, in various stages, with illustrations, may be found in the paper prepared by Mr. Wilson ${ }^{1}$ at the St. Andrews Marine Laboratory, already referred to. It may be well to note that Mr. Wilson found ova and spermatozoa, 'presenting no appreciable difference from those taken from the full-grown adults,' in mussels only one-eighth of an inch long. This raises the question as to what a full-grown adult is. Every one, we may presume, has a general idea as to the average size of a mussel as used for bait, or as seen growing on rocks on the coast, but if inquiry be made into the sizes of mussels in different localities it will be found that the result is confusing. If a mussel becomes an adult whenever it is capable of reproducing its species, then we are safe in saying that adult mussels may be found varying in size from one-eighth of an inch to at least twice the size of what most people would consider to be a full-grown mussel, or a large mussel suitable for purposes of bait. Range of mature size was shown to the writer some years

1 Fifth Annual Report of the Fishery Board for Scotland, I887, Appendix F, No. vi. p. 247. 
ago in a progressive series of mussels prepared by Mr. Thomas Scott, one of the naturalists to the Scottish Fishery Board.

It is probable, however, that the majority of small mussels which actively reproduce their species, have been retarded in their growth by the presence of unfavourable conditions of life. They are not necessarily young mussels.

The rate of growth is a subject concerning which much diversity of statement is possible, since it depends to a very great extent upon a variety of conditions. In studying this point, however, we gain a considerable amount of information which is extremely useful, since the conditions of favourable and of unfavourable growth are brought out.

If a quantity of spat in its early free-swimming condition is carried by currents along a rocky coast, where masses have become detached from the cliffs and stand washed by the ocean tides, the young mussels, on reaching the stage at which they sink and attach themselves, must necessarily make use of the rocks and boulders amongst which they are thrown.

Here, if they are examined after they have grown for two or three years, it will be found 
that those attached to the land or sheltered side of boulders are much larger and fuller than those which are exposed to the force of the waves.

If, on the other hand, the spat has settled on the rich flats of some suitable estuary, we find that there is a much more uniform growth, and that compared with those grown for the same length of time on the rocks of an exposed shore, the average rate of growth has been much more rapid. The difference is due to the additional amount of suitable feeding brought into the estuary by the fresh water, and to the shelter from storms.

Another factor, however, which greatly influences the growth of a vast number of mussels, is overcrowding. If we take into consideration the enormous number of young which a single pair of mussels may produce (probably between two and three million) it is no matter for astonishment that a considerable proportion of that number should be annihilated, through want of space for healthy growth. If a cluster of mussels growing in a natural condition be examined, the large ones will be found to be much less numerous than the minute individuals which, in closely packed array, entirely fill up the interstices around the shells of the large and specially favoured few. 
These small ones are prevented from growing through being squeezed almost to extinction, like the foot of the Chinese lady. In very many cases, in fact, it seems likely that those which survive do so largely because they have been able to make room for themselves by squeezing their neighbours to death. Mussels on the margin of a cluster are always found to be comparatively large and healthy.

When we consider the circumstances under which spawning takes place, the warm weather of the months in which it most commonly occurs, and recollect that the shell-fishes must necessarily be covered with water before fertilisation and early development can be effected, it is clear that to obtain a really good fall of spat the beds should not be left too long uncovered during low water. The longer a hot sun or a cold shower can beat upon the ripe mussels, and so produce an extreme rise of temperature and dryness of the beds, or the more a sudden fall of temperature and flooding by rain-water can affect them, the less chance is there of a large number of eggs being produced.

It should, I think, be more often recollected, that although the mussel is so largely found 
NATURAL HISTORY OF THE MUSSEL 55

between tide marks, it is also capable of thriving perfectly at some distance from the shore, and in fairly deep water. The Government beds of Holland, for instance, which are hired out to culturists, are usually laid down where the water is a depth of from 7 to 15 feet at low tide. These mussels grow commonly to a length of 2 or $2 \frac{1}{2}$ inches. They are therefore of excellent size, and are much used as food both in Holland and in France. Some of the beds at Lynn and Boston also are constantly covered by water. The Skibo beds of Meikle Ferry, Sutherlandshire, are mostly covered by 10 or I 5 feet at low-water springs, and in almost all the estuaries of our larger rivers the channels contain mussel beds of greater or less extent.

The favourite position of the mussel, however, if such an expression is allowable, may be said to be a few feet above the level of low-water mark, if there is a considerable rise and fall of tide; or between the low levels of spring and neap tides. In this position the rate of growth will be more rapid than is possible when the mussel is high above low water, and exposed to the air for long periods. The feeding and environment of different localities largely determine what the rate 
of growth will be, and therefore a hard and fast statement cannot be made.

Taking Scotch beds collectively, however, we are inclined to estimate that the mussel when placed in the favourable estuarine localities indicated above, reaches a size suitable for bait, i.e. about 2 inches, in about three years. In less favourable positions, where the mussels are long uncovered, and therefore kept without food and free respiration, or are in pure sea-water, and in rather exposed shores, the time taken to reach the size indicated appears to vary from four to eight or ten years.

The mussel will grow on almost any natural sea or estuarine bottom, but the rich flats, where sand and gravel are covered by mud charged with diatoms, infusoria, spores of algæ, and other vegetable matter, rear large fat mussels most quickly.

The natural enemies of the mussel are the starfish or cross-fish, and the whelks. The havoc which can be done by inroads of these creatures is astonishing. In the evidence given before the Mussel Commission, three instances occur where entire destruction of beds is attributed to star-fish, and one instance in which it is traced to whelks. 
Complaints as to injury, occur very frequently, and the practice, which is not uncommon, of throwing star-fish overboard when sorting the lines on nearing harbour, is also severely condemned.

The sea-urchin is believed by some to do damage to mussel beds, but it does not occur with great frequency between tide marks.

The increased need for bait, and the lack of proper protection, are without doubt the two great causes of decline, the fishermen not being sufficiently alive to the fact, that if a bed is reduced by more than its average increase, a process of depletion is started which can end only in the ruin of the scalp.

The natural position of many beds is such as to lay them open to serious danger from floods, shifting sands, gales, and frost. This is more especially the case where the beds are situated along the banks of a river-mouth and are long exposed during low tide. A frost, if allowed to act too long on scalps, weakens and paralyses the mussels so that they lie with their shells open, and a gale following the frost, a condition not uncommon, raises silt in the broken water of the rising tide, which is carried into and over the mussels. Frost is, of course, more liable to have 
this effect where much fresh water remains amongst the mussels.

\section{Favourable Conditions and Treatment of Scalps.}

The presence of fresh water in the neighbourhood of scalps is considered by some to be disadvantageous, and it is possible to point to 'deep water beds' away from much influence of fresh water, which carry uniformly large-sized shell-fish. But, as we have already shown, the most natural habitat of the mussel is in estuaries where a considerable proportion of fresh water is present, where at the same time each rising tide carries up salt water. The condition might be described as a constantly varying one,- - at one time fresher, at another time salter. The average specific gravity could only be determined at any one naturally fruitful bed, by a long series of observations embracing all extremes. I have no doubt, that if this were done at a number of places, we could eventually determine without much difficulty what the most beneficial water conditions are; but at the same time we should probably also find that the mussel could thrive perfectly by adapting itself to the particular conditions of different localities. An extreme of salt water tends to 
NATURAL HISTORY OF THE MUSSEL 59 thicken the shell, an extreme of fresh water weakens the animal and impoverishes its shell. In either case the best bait mussel cannot be produced.

Scalps, to grow mussels rapidly and well, must not be long uncovered by the tide. On a shelving beach this can often be seen most clearly at low water, large mussels being found near the water and a gradually diminishing series extending up the beach, the mussels being all of the same age. An exactly similar condition can be observed in the case of plantations of Scotch fir on a mountain side,-a rich, full growth at the foot of the slope, a struggling existence at the top.

Beds therefore should be protected as far as possible from the deposition of silt. This evil, if present, can only be remedied by transplanting the mussels from the high bed, and causing the available currents to scour and wash down the deposit. The mussels can then be replaced, or fresh seed sown. To do this satisfactorily a considerable area of mussel ground must be at command. In many places scouring cannot be satisfactorily accomplished because of the small area at command. When it is quite evident that beds are too high, a delay in transplanting, so as 
to reap a passing harvest, is false economy. Mussels should rather be removed from some other ground. Transplanting should also be freely carried out wherever it is clear that any seedmussels are not growing rapidly, through being too long dry at low water or too much exposed to rough tides of pure salt water.

Transplanting should also, of course, be resorted to in all cases where seed is required to cover a section of scalp from which a crop has been taken. A convenient position to find seed for this purpose is frequently in the deeper channels at the margins of scalps, where spat has fallen out of ready reach. The procuring of seed is in some localities difficult, but if cultivation were more general, a supply of seed would be abundant, which, if necessary, could be brought considerable distances and sown on the small home beds of fishing villages.

Seed taken from 'deep water beds' will not admit of being carried so well as seed which is inured to exposure from being left bare by the tide.

In cases where bait is regularly supplied year after year, the system of cropping beds in rotation, or in sections, if a large scalp, should always be practised, care being taken to have as many annual crops as will suffice for the complete growth 
NATURAL HISTORY OF THE MUSSEL 6I

of the seed. Want of care in this matter is astonishingly common, and hence the violent fluctuations which frequently appear in some localities. This evil seems to be most easily brought about by allowing more than one proper crop of mussels to be taken in one year. The next year's crop is in this way reduced, and the evil gradually spreads to all the crops in succession. Sufficient seed is not obtained to recoup the beds, and a few years of desolation follow.

In lifting mussels, the rake, in the opinion of the writer, is decidedly preferable to the dredge. Short rakes can be readily used on dry scalps or in shallow water, and heavier implements with long larch pole-handles in water the depth of I 5 feet.

Dredging, although commonly employed to procure mussels, may, under certain conditions of bottom, as seen in the shifting sands of the Dornoch Firth, produce a tendency to cover the mussels with sand. In other localities, where the current is strong and the mussels cling firmly to the bottom, the dredge may crush and destroy numbers. Walking on mussel beds should not be allowed, since damage of the same nature is the result. 
The form of rake used at St. Andrews is considered very serviceable, and may be described as follows: The iron head, to which the polehandle is attached, has the toothed bar bent backwards at each end. Each bent part carries two teeth. There are about seventeen teeth in all. The head is about 28 inches across, and each tooth is Io inches long, slightly curved backwards at the tip. A shallow net is fixed above the toothed bar by a bow of strong iron wire, which passes from end to end of the bar and is caught in the centre by an attachment to the root of the pole where the iron joins the wood. The netting is $3 \frac{1}{2}$-inch mesh, made of 'marlin.' In making the rake, the teeth are first screwed into the bar and then riveted. ${ }^{1}$ A similar rake is used in Holland.

The use of a riddle, for separating small from great, in transplanting mussels, is also of great service, since it not only ensures that the shellfish about to be bedded are of fairly even size, but is most economical in saving great numbers of small mussels which otherwise would be allowed to disappear. A riddle is commonly used at King's Lynn, where the manager of the 
NATURAL History OF THE MUSSEL 63

beds, who comes from Holland, makes all fishermen pass their mussels through this gauge on the beds, and then re-spreads the remaining small mussels with a shovel.

This riddle is about 2 feet in breadth, the rim, $3 \frac{1}{2}$ to 4 inches deep, being of wood, as in an ordinary gardener's riddle or sieve. Across this frame, fine stout rods are placed, and at right angles to these, the wires are stretched at a distance of $\mathrm{I}$ inch from each other. This wire mesh is sometimes slightly reduced, but the excuse cannot here, as in the case of herring nets, be shrinkage. If the riddle is intended as a gauge, the I-inch space between the wires should be carefully maintained.

At King's Lynn, mussels intended for laying down, which have been lifted in clusters, small and great together, are first separated by hand, and are then riddled and spread by means of shovels. A single worker can separate six to eight bushels during one ebb-tide. Transplanting in a more wholesale way is also carried on, however, and is in ordinary circumstances all that is required, provided the mussels are not spread too thickly. As a general rule, we might say that, if possible, no mussel should be allowed to lie 
on top of another mussel-every one should rest on the bed. If spat settles on other mussels, the difficulty arises in its most awkward form. The only thing which can then be done is to allow the spat to grow till it is large enough to be separated, and this separation can most readily be effected by means of the hand and riddle. I understand that the Ferryden Society crop about 40 acres in the year, supplying $12,000-14,000$ measures of 90-96 lbs., and frequently transplant their mussels twice. $£ 200$ per annum are paid in wages to the workers, and the price of from 6d. to $8 \mathrm{~d}$. a basket paid by the fishermen makes up the sum required for this and other expenses. The fact that the fishermen of Montrose are better off in their supply of mussels than any others on the coast, speaks to the success of the methods employed.

Star-fish can do irreparable damage to seedbeds, and should, like all other enemies, such as whelks and urchins, be constantly gathered.

Every individual locality, on account of its surroundings, will naturally be found to require its own peculiarities of treatment, just as sisterships frequently require different handling; but the sketch given above of the methods which 
experience has shown are successful, will, it is hoped, serve as a basis of knowledge to those who desire the improvement either of particular scalps or of the supply of bait in any district.

To the writer it seems most probable that, as Professor M'Intosh has already indicated, the initial expenditure required to start successful farming of mussels will be repaid whenever the various sections of a fishery have been resuscitated and fully brought into action. The condition of any bed to be regulated will determine to a very large extent what the initial expenditure is likely to be. If it is necessary to bring seed from a considerable distance, or employ labour to clear or prepare the ground, expenses will be greater than in cases where, as in Inverness and Cromarty Firths, for instance, the ground is naturally most suitable and nuclei of seed-beds exist. In no case, probably, will initial expenditure be great, and when in three to four years systematic cultivation has been established, any bed should easily produce a sufficient supply of marketable mussels to enable those in charge to pay all expenses if not to make a profit.

The gathering of the spat of the oyster is nowa-days almost entirely accomplished by means of 
artificial collectors. These usually consist of arrangements of limed tiles placed so that the current carrying the spat will play freely upon them. So we have the gabarét, bouquet, and planche collectors of France, and the vast areas of tiles in Holland, arranged as if in brick fields, described simply as en ruchès. For collecting mussel spat, and growing and fattening mussels, only one system, the bouchot, is adopted. It is employed only in France, but has been advocated in our country, and tried experimentally in a few places. A description of culture would therefore be incomplete without it. At the same time, I think it is certain, that although the bouchot would be a useful accessory on the mussel farm, a perfectly adequate supply of bait could be procured without it. The system is dealt with in the next chapter. 


\section{H A P T E R I V}

THE FRENCH BOUCHOT SYSTEM OF CULTURE

THE story of the commencement of the bouchot system of mussel cultivation has already been published, but may be retold in a few words.

In $1035^{1}$ (Quatrefages, Souvenirs d'un Naturaliste; Paris, 1854) an Irish barque was wrecked in the Bay of Aiguillon, near the village of Esnandes. One man, named Walton, survived. He was kindly received by the French fishermen, and lived amongst them for many years. In addition to introducing an excellent variety of cross-bred sheep to the district, by means of the surviving live stock of his ill-fated ship, this man erected traps for the capture of sea-birds and duck, which frequented the mud-flats of the bay at night. Noticing that the piles supporting his nets became coated with mussels, and that these

${ }^{1}$ Stated as II 35 by Bertram, Harvest of the Sea, p. 410; London, 1865 . 
shell-fish grew to a larger size than those on the shore, this enterprising person set up a hurdle, on which he received spat and reared the mussels for food. From this beginning, the apparatus gradually developed into what is now known as the bouchot, as seen at the villages of Esnandes, Charron, and Marsilly, and at places of less importance in the neighbourhood. Miles of mudflats are now covered by long fences of piles and wattling. The piles consist of stems of trees cut to about 12 feet in length, and averaging about 6 inches in diameter. These are sunk about half their length in the mud at a distance of 2 feet from each other. Until recently, it was customary to arrange these rows of piles in a series of $V$-shaped structures, the pointed end of the $V$ being directed towards the open sea, so as to minimise the force of the waves, each arm being 200 to $25^{\circ} \mathrm{O}$ metres in length. Professor Herdman, ${ }^{1}$ reporting on the condition at present existing, states that the $\mathrm{V}$-shaped arrangement has been generally given up for the more simple and compact arrangement of parallel rows. He says: 'The rows are about 30 yards apart, and

${ }^{1}$ Report upon the Methods of Oyster and Mussel Culture in use on the West Coast of France, Proc. and Trans. Liv. Biol. Soc. viii. I893-94, p. I21. 
each has several hundred posts.' They are arranged at right angles to the shore. The tide ebbs for a great distance on the mud-flats of this coast, and the bouchots are placed in series farther and farther from shore. It has for very many years been found convenient to transplant the mussels from one series to another, at successive stages of growth, beginning at the section farthest from land, since it is arranged for the purpose of spat-collecting alone. By the time a brood has reached its final resting-place, and is ready for market, four or five changes at least have usually been effected.

The development of the system appears to have proceeded to a considerable extent towards the multiplication of these sections. In process of time, considerable confusion has arisen in the use of local names for the various sections. Twenty or thirty years ago the outermost section was called bouchot du bas, or bouchot d'aval. The latter name is still retained, but the former one, according to Herdman, ${ }^{1}$ is now applied to the third section, the order being bouchot du d'aval, bouchot batisse, bouchot du bas, bouchot batards, and finally bouchot d'amont. So far as we in this 
country are concerned, the order and accuracy of these local names matters little, so long as we understand the method upon which the whole series are worked.

The first or outermost bouchot is in such a situation as to be uncovered by water only during low spring tides. At low springs, therefore, the posts are placed in position, and, being at all other times surrounded, or covered altogether by water, serve as suitable places of attachment for the free-floating embryos. In the genial climate of western France, the fixation of the spat usually takes place during February or March. By July each young mussel has grown to about the size of a haricot bean. The first of the series of transplantings then takes place to the other bouchots, the piles of which have wattle or basket-work (locally termed clayonnage) thickly intertwined to within a short distance of the ground. (The space of about a foot is left to allow the soft and easily silted mud to pass, without choking up the wattle-work.) The seed is detached from the outer posts by means of long hooks, and is tied up in small bags of old netting. These bundles are then taken by the boucholeur in his mud punt to the second section, where they are placed 
in the spaces of the branches which are used as wattle-work.

The young mussels soon attach themselves to the bouchot, and the netting is allowed to rot and fall off. The bouchots, in this way, soon become dense walls of black mussels. When it is necessary to thin them, or to make room for another brood, a second transplanting takes place. This work goes on from one section to the other, the mussels approaching nearer and nearer to the shore; at one time exposed at low water neaps, and at last brought close to the high-water mark. When the mussels are large enough the netting is dispensed with, and they are individually pushed into the spaces of the wattle. The work has to be carried on during low tide, and is practised day and night. In little more than a year the mussels are considered ready for market, being about an inch and a half long. They are seldom reared to a greater size than 2 inches. The mussels, from being, in the course of their steps nearer and nearer to shore, left for an increasing length of time uncovered by the sea, become inured to exposure, and are found to travel better and remain fresher for a longer period.

These mussels are used for food, and are sold 
extensively amongst the poorer classes of France. During the time of spawning, February till April, they are however out of season.

In erecting bouchots in this country, it should be remembered that we have few localities with mud as deep as that found in the Bay of Aiguillon. It would therefore be necessary not merely to sink the posts, but, in the majority of cases, to drive them.

A bouchot set in an estuary would necessarily have its apex turned towards the direction from which the strongest current is expected, if the V-shaped structure were used.

The bouchot system has been tried in five places in Scotland, always on a rather small scale, with the view of testing the method before any great expense was entered upon.

It was tried at Little Ferry by the Duke of Sutherland's manager; at Tain on the Corporation beds; at Inverness by the Town Council; at Montrose by Mr. Johnston; and at St. Andrews by Mr. Comyn, acting under instructions from the Scotch Fishery Board.

In all these localities disaster of some sort followed.

At Little Ferry, gales washed the mussels from 
the wattling; at Tain one bouchot was covered by shifting sand and another stood for ten years without yielding much result-the positions chosen for the erection of the posts having been unfortunate; at Inverness the result was also counted unsatisfactory, and the expense in handling the mussels prohibitive; at Montrose, on the beds of Messrs James Johnston and Sons, the bouchot was not found to work with great advantage, trouble being experienced through the shellfish falling off the laths which were used instead of branches. Mr. James Johnston, however, in his evidence before the Mussel Commission, seems to regard the bouchot with some favour as a supplemental method of collecting seed. The bouchot erected in the Eden by Mr. Comyn had, unfortunately, but a short existence, on account of a gale and heavy flood. The writer, while cruising in St. Andrews Bay, picked up some of the wreckage. The experiment was, I believe, in part successful, and if the model structure had been driven into the ground with sufficient force, might have gone far to show the result of this method of culture on our coast. Professor M'Intosh had previously experimented on the Eden beds in a similar manner, by erecting branches at various 
localities, some of which collected a considerable amount of seed.

From the evidence given before the Mussel Commission, it appears that the bouchot erected by the Fishery Board cost between $£ 50$ and $£ 60$, a sum which must be considered as a serious handicap in the initial outlay for a bed. The price of labour in this country, being rather higher than that in the west of France, also acts as a hindrance to the adoption of the system, since much tending is necessary. In places where, for the proper cultivation of extensive mussel scalps, a considerable number of men are employed, it might, however, be possible to erect and tend bouchots as an accessory means of spat-collecting It seems certain, in fact, that great quantities of spat might be secured on bouchots, just as we might collect, were it worth while, by the more elaborate means employed for oyster culture; but the great advantages of the bouchot system in producing fat and clean mussels seem to apply more to the cultivation of the shell-fishes for food, as in France, than to their growth as fishermen's bait in this country. In addition, as Professor Herdman very justly points out, ' ${ }^{1}$ There can be

1 Loc. cit. p. 124. 


\section{BOUCHOT SYSTEM OF CULTURE 75}

no doubt that the chief reason of the extensive cultivation by means of bouchots in the Bay of Aiguillon is simply that no other plan would succeed there. The mud is so very soft, and so constantly forming, that mussel beds could not be established.'

The large natural areas at command in Great Britain for culture on the bedding system are without any doubt more than sufficient to produce, if protected and regulated, bait and seed mussels with which to maintain the nation's demand. 


\section{CHAPTER V}

LEGAL ASPECTS OF THE SHELL-FISH FISHERIES

In this chapter it is my purpose to give a sketch of the legal conditions under which shell-fish beds are held in this country, in order that those desirous of undertaking the cultivation of either oysters or mussels may have a general understanding of rights and obligations. I have incorporated, also, information as to the steps necessary in procuring Fishery Orders.

The substance of the chapter is simply a compilation from authoritative works on the subject, and is introduced here in a popular form. For fuller information, reference must be made to the works themselves.

The territorial water over which, and over the bottom of which, jurisdiction is possible, is contained within a line drawn at a distance of three 
miles from the land, being, theoretically, the distance of a cannon shot. This belt of water includes all bays, creeks, and inlets which may measure more than three miles from their innermost point, but which are not more than ten miles across at the mouth. Beyond this belt, the sea may be considered as the common fishingground of all nations.

Rights of taking shell-fish in different localities.

Distinction may be drawn between three conditions :

A. Scalps situated on the beds of private rivers, or on sea-bottom alienated from the Crown to private individuals, by special grants.

B. Scalps in public estuaries, and on the national sea-bottom and foreshore generally.

C. Scalps in the bed of the ocean beyond the three-mile limit.

We need not consider the last, since the scalps are common to all nations, and cannot therefore be regulated by any but by International Law. In dealing more especially with division $\mathrm{B}$, since the scalps which fall under this heading are those of 
greatest importance in the present connection, we shall, at the same time, strive to include all matters of interest to those who may seek private right of fishery, or whose beds may naturally be classed under heading A.

In public estuaries, rights of navigation are considered legally to have a claim superior to those of fishing. The public are still entitled, although a grant of fishings exists, to free passage in all such estuaries, and on the banks. The sea and the sea-shore are in the same way free for all purposes of navigation. Further, a private right of mussel-fishery does not exclude the public right of white-fish fishing in water which may cover the scalps. At the same time, by the Sea Fisheries Act of I868, this public right is restricted to the use of such methods as are not injurious to shell-fish.

Foreshore, for all legal purposes, is that part of the soil of the country situated between high and low water marks. Estuarine beds are therefore very largely situated on the foreshores as well as on the bottom of the channels which are constantly covered by water. 


\section{Shell-fish scalps are the private property of the Crown.}

At one time the legal opinion seems to have been that shell-fish scalps were public property held in trust by the Crown.

The case of The Laird of Grant v. Rose of Kilravock, I764, seems to be generally cited as showing this. Shairp, ${ }^{1}$ however, seems to regard the matter doubtfully. The report of the case runś as follows' ${ }^{2}$ : In a private river a mussel scalp belongs to the proprietor of the ground adjacent; in a public river it belongs, like white fish, to the public, and consequently the use of it is open to every one of the lieges. But as such general use tends to root out every mussel scalp, expediency, supported by practice, has introduced a prerogative in the Crown of gifting mussel scalps to individuals, which has the effect to preserve them by the exclusive use given to the grantees.' Any prerogative of gift which the Crown may have possessed gradually became established as absolute ownership. In passing, it is interesting to note that, even at this early date, the gifting of scalps had to be resorted to for the

1 Stewart's Law of Fishing, Shairp, 2nd edition, p. 66 (note .

2 Grant v. Rose, I764, M. I2,80I. 
purpose of averting the ruination of the scalps. White-fish fishing continues to be held by the Crown in trust for the people; but the right of taking mussels, oysters, and other shell-fish, as well as the title to the soil on which the shell-fish congregate, is, in Scotland, part of the patrimonium principis, or hereditary revenues of the Crown. The right of fishing and the title to the soil are both therefore alienable by Crown grant. The case of The Duchess of Sutherland v. Watson and Others ${ }^{1}$ (Ioth January I868), to which reference has already been made in Chapter II., established this point. Mr. A. Asher, Q.C., in his evidence before the Mussel Commission, ${ }^{2}$ refers to the case in question as follows: 'The. Duchess of Sutherland, as grantee of the Crown, has an exclusive right of property in the mussel scalps within the grant, whether these mussel scalps are situated in the foreshore or in deep water beyond the foreshore, but, of course, within the territorial waters.' Later, he also says: 'A survey of the development and progress of the law on this subject appears to me to show that the right of mussel-fishing, which was originally regarded

16 Macph. I99.

2 Report of the Mussel and Bait Beds Commission, ISS9, p. I53. 
as a trust in the Crown for the public, came by degrees to be regarded as part of the patrimonial property of the Crown, and so susceptible of alienation, and to be made the subject of grants to individual owners, with a view to an increased and more regular supply of mussels being thus made available for bait. If, as there is strong reason to suspect, the private ownership of mussel scalps, as hitherto exercised, has not attained that object, then I think some other arrangement should be tried.'

\section{The Transfer or Granting of Right from the Crowen to the Subject.}

This implies a certain obligation on the part of the grantee to carry out the purposes for which the right of fishing is granted. This obligation acts as a certain protection of the public interest. The estate is an heritable one held by feudal title. In cases where the grant is not given to an individual or to a company for purely commercial purposes, an additional obligation may rest upon the grantees. The scalps at the mouth of the Eden, for instance, are held by the corporation and inhabitants of St. Andrews, in the interest, first of all, of the fishermen of the neighbourhood. 
In I869 a case arose (Magistrates of St. Andrews v. Wilson $)^{1}$ on account of the fishermen being dissatisfied with the management of the scalps, and having attempted to take the matter into their nwn hands. In the report of the case it was stated that the fishermen were justified in applying to the Court, but that they were not at liberty to help themselves to mussels or take over the management. The result of this case is of some interest and importance, in view of the proposals, which have occasionally been made, for the formation of fishermen's societies for management of local mussel scalps.

With reference to the ground upon which mussel or oyster scalps may be situated, it does not necessarily follow, if a specific grant of fishing is procured, that an exclusive use of the foreshore or solum is obtained. And, on the other hand, ${ }^{2}$ " it has not been decided whether conveyance of the foreshore, or of the solum on which the oysters or mussels are situated, conveys a right of taking the fish, though they are not mentioned in the charter.'

In 1885 all powers with regard to the oyster and mussel fisheries of Scotland, previously held

17 Macph. I I05.

2 Stewart's Law of Fishing, 2nd ed., Shairp, p. 69. 
by the Board of Trade, were transferred to the Fishery Board. ${ }^{1}$

The patrimonial rights of the Crown, however, are still intrusted to the keeping of the Commissioners of Woods and Forests. The powers of the Fishery Board are those of management and regulation.

Specific grant of mussel or oyster fishings has, therefore, to be procured, in Scotland, by charter, from the Fishery Bcard, who receive consent from the Commissioners of Woods and Forests.

Statutes regulating Mussel fishing.

Act IO and I I Vict. c. 92 is entitled 'An Act for the Protection of Mussel Fisheries in Scotland. [22nd July i 847].'

It will be found in full in Appendix A, pp. 93, 94. By this Act persons unlawfully taking mussels from mussel beds are declared guilty of theft, and liable to imprisonment not exceeding the term of one year.

Also, persons fishing or trespassing in any mussel fishery are deemed guilty of attempt to commit theft, and are subject to fine or imprisonment.

I By the Sea Fisheries (Scotland) Amendment Act, I885 (48 and 49 Vict. c. 70 § II). 
In order that offenders may be convicted, it is necessary that the fisheries be properly 'marked out or known as such,' since scattered patches of mussels are not included in the patrimony of the Crown, and therefore cannot be made subjects of theft.

An exactly similar Act exists for the protection of oyster fisheries. ${ }^{1} \quad$ It is an extension of an older English Act (7 and 8 Geo. IV. c. 29), and gives power for the punishment of offenders in the same way. The want of interest among proprietors is singular in view of the powers existing with regard to the regulation of mussel fisheries. We have seen that proprietorship does not necessarily include exclusive right of fishing, but by the Sea Fisheries Act of I868, 3 I and 32 Vict. c. 6, clause $5 \mathrm{I}$, it is settled that shell-fish on a private bed, which is owned by any one independently of the Act, are the actual property of the owner. (Part III. of this long Act will be found in Appendix B, pp. IO3-I2I.)

Offences under this Act have been summarised as follows :

(a) The using any implement of fishing, except a line and hook, or a net adapted solely 13 and 4 Vict. c. 74 . 
for catching floating fish, and so used as not to disturb or injure in any manner any oyster or mussel bed.

(b) The dredging for any ballast or other substance, except under a lawful authority for improving the navigation.

(c) The depositing of any ballast, rubbish, or other substance.

(d) The placing any implement, apparatus, or thing prejudicial, or likely to be prejudicial, to the beds, except for a lawful purpose of navigation or anchorage.

(e) The disturbing or injuring in any manner, except as last aforesaid, any oyster or mussel bed.

Any person committing any of the above offences is liable to a penalty of $£ 2$ for the first offence, $£_{5}$ for the second, and $£_{\mathrm{I} O}$ for the third offence, besides being liable in damages.

With regard to oyster fisheries, the Fisheries (Oyster, Crab, and Lobster) Act, I 877, determines the periods during which it is illegal to sell oysters. Deep-sea oysters may not be sold between I $5^{\text {th }}$ June and $4^{\text {th }}$ of August, while the close-time for ordinary territorial oysters extends from i $4^{\text {th }}$ May till 4th August. The Act also empowers 
the Board of Trade to prohibit or restrict, on local application, any dredging for oysters on given banks.

Another Act which must be included under the present heading is the Sea Fisheries (Clam and Bait Beds) Act, I88I. By it the Board of Trade is empowered to protect bait beds from injury by beam-trawls. Application for protection of this kind must be made by some one representative of the fishermen of the locality, or by town councils, proprietors, or authorities maintaining or regulating any harbour.

Greater detail of these two Acts will also be found in Appendix B.

Appropriating and Regulating Orders.

The following quotation from Part III. of the Sea Fisheries Act, I 868, sufficiently shows the effect of granting Appropriating and Regulating Orders.

'40. Where an Order of the Board of Trade under this part of this Act confers a right of several oyster and mussel fishery, the persons obtaining the Order, in this Act referred to as the grantees, shall, by virtue of the Order and of this part of this Act, but subject to any restrictions and exceptions contained in the Order, have, within the limits of the fishery, the exclusive right of depositing, propagating, dredging, and fishing for, and taking oysters and mussels, 
and in the exercise of that right may, within the limits of the fishery, proceed as follows, namely, make and maintain oyster and mussel beds, or either of them, and at any season collect oysters and mussels, and remove the same from place to place, and deposit the same as and where they think fit, and do all other things which they think proper for obtaining, storing, and disposing of the produce of their fishery.

'41. Where an Order of the Board of Trade under this part of this Act, without conferring a right of several oyster and mussel fishery, confers a right of regulating an oyster and mussel fishery, and imposes restrictions on, or makes regulations respecting, the dredging and fishing for and taking oysters and mussels, or either of them, within the limits of the regulated fishery, or imposes tolls or royalties upon persons dredging, fishing for, and taking oysters and mussels, or either of them, within the limits of such fishery, the persons obtaining the Order, in this Act included in the term the grantees, shall by virtue of the Order and of this part of this Act, but subject to any restrictions and exceptions contained in the Order, have power to do all or any of the following things; namely,

'(a) To carry into effect and enforce such restrictions and regulations :

'(b) To levy such tolls or royalties :

'(c) To provide for depositing and propagating oysters and mussels within the limits of the fishery, and for improving and cultivating the fishery.'

Fishery Orders may be obtained, in Scotland, from the Fishery Board; in England from the Board of Trade; in Ireland from the Inspectors of Fisheries. Information as to the proper form 
for lodging an application in Scotland will be found in the official regulations of the Fishery Board in Appendix B. It is, as nearly as possible, identical with the document of the Board of Trade.

The current Report of the Fishery Board ${ }^{1}$ contains a precise statement concerning Appropriating Orders. Since this is of interest in the present connection, one or two quotations may be made from it.

' The effect of an Appropriating Order is to confer on the grantee a Parliamentary title for sixty years to a definite portion of the foreshore, and he acquires a right of property in the oysters and mussels therein, subject to the condition that he shall properly cultivate the oyster and mussel ground, in accordance with certain restrictions and regulations designed for the protection of the public interest.'

The expenses necessary to procure an Order have long been considered prohibitive, and have been complained of by many. The transference of the management of shell-fish scalps from the Board of Trade to the Fishery Board was accomplished largely in order to reduce this expense,

1 Truelfth Annual Report, Part I. p. xxiii (for I\$93, pub. I894). 
and so to encourage the taking up of the foreshore. Referring to this in the Report, it is stated: "The Board has been able to reduce the cost to about $£ \mathrm{IO}$, but nevertheless it is a matter of regret that this valuable Statute has not been taken advantage of to a much greater extent.'

'The Board is not disposed to look with much favour on grants being made, except on very rigid conditions, to the individual owners of adjacent property, but there is no reason why the fishermen themselves should not, under an Order, take the cultivation of oysters or mussels, or both, into their own hands, by means of a committee of their own appointment.'

With reference to oyster beds, it is stated later on: "The beds must be made the actual property of some one person or some one community.' And with regard to mussels (p. xxvi): 'A bed of mussels naturally lends itself to the work of revival, and the management required would be inexpensive. The Board entirely agree in the opinion expressed by Professor M'Intosh, in a published pamphlet, that if properly and wisely managed, a mussel fishery will rapidly repay the small initial expense, and might indeed be made largely profitable.' 
Both in Scotland and in Ireland the facilities for individuals taking up the cultivation of the foreshores are greater than is the case in England, where, though the management and regulation is vested in the various Fishery District Committees (5 I and 52 Vict. c. 54) an Appropriating Order must still be obtained only with difficulty and at considerable expense from the Board of Trade.

With regard to the improvement of shell-fish beds, the Fishery District Committees are powerless if expenditure of money is necessary. Protection and regulation are possible, but improvement by cultivation, or even transplanting, is beyond the powers conferred by the Sea Fisheries Regulation Act, I888, in its present form.

In Ireland, Inspectors of Fisheries have the control in their own hands, and are empowered (5 and 6 Vict. c. 106, § I3) 'to grant to any owners or occupiers of land bordering on the sea, or any estuary, or to any person, with the consent of such owner or occupier, licences for the formation of bait beds between high and low water marks, and in all other places adjacent to their respective portions of lands, as shall be suitable for the purpose. Such beds to be held as private property, and the licencees to hold exclusive 
control over them so long as they shall be owners or occupiers of such land. Licence to be granted only where no public banks or beds at present exist.'

The prosperous condition of shell-fish beds in other countries (notably in France), which have been cultivated by the labour of many lessees or grantees, justifies the belief, as may be gathered from the Fishery Board's Report, from which quotation has just been made, that the system is applicable to the depleted or declining mussel beds of our own country, with equal prospects of success. It therefore becomes necessary to develop such methods of leasing as will be at once simple and cheap, while producing the greatest benefit both to the lessee and to the country.

The hesitancy shown by fishermen and others, both in Scotland and Ireland, in taking advantage of the facilities now offered, seems largely to result from a lack of confidence in the personal advantages to be gained from culture, as well as from a distrust of the available protection against a long established custom of promiscuous mussellifting.

In the opinion of the writer, this condition will 
only be remedied when a State control is established which will force the fishermen to protect their own interests, while complying with necessarily strict regulations.

It is believed further that the fishermen of this country are now anxious for State interference with regard to the regulation of the scalps, and will not hesitate to accept conditions which, being imposed on all alike, are framed for the improvement of the national bait supply. 


\section{A P P E N D I X A}

\section{ANNO DECIMO \& UNDECIMO \\ VICTORI $Æ$ R E G I N $\nRightarrow$ \\ CAP. XCII.}

An Act for the Protection of Mussel Fisheries in Scotland.

[22d July i 847.]

Whereas Mussel Fisheries in Scotland have been the Subject of Royal Grant and of private Right : And whereas it is expedient that certain of the Provisions of an Act passed in the Session of Parliament held in the Third and $3 \&{ }_{4}$ Vict. Four Years of the Reign of Her present Majesty, for the ${ }^{\text {C. }} 74$. better Protection of Oyster Fisheries in Scotland, should be extended and apply to the Mussel Fisheries of Scotland: Be it therefore enacted by the Queen's most Excellent Majesty, by and with the Advice and Consent of the Lords Spiritual and Temporal, and Commons, in this present Parliament assembled, and by the Authority of the same, That if any Person in that Part of the United Kingdom Persons un. called Scotland shall wilfully, knowingly, and wrongfully take and carry away any Mussels or Mussel-Brood from any Mussel Bed, Scalp Laying, or Fishery, being the Property and in the lawful Occupation of any other Person guilty of or Persons or Body Corporate or Politic, and sufficiently marked out or known as such, every such Offender shall be deemed guilty of Theft, and being guilty thereof shall be liable to be sentenced to Imprisonment not exceeding the Term of One Year. 
Persons unlawfully fishing or trespassing in any Mussel Fishery deemed guilty of an Attempt to commit Theft.

Nothing to prevent Persons Jawfully entitled, from fishing for floating Fish.

Nothing to prevent Persons from exercising legal Rights.

ct may be amended,etc.
II. And be it enacted, That if any Person shall unlawfully use any Dredge, or any Net or Instrument or Engine whatsoever, or shall trespass within the Limits of any Mussel Bed, Scalp Laying, or Fishery in Scotland, being the Property and in the lawful Occupation of any other Person or Persons or Body Corporate or Politic, and suffciently marked out or known as such, for the Purpose of taking Mussels or Mussel-Brood, though none shall be actually taken, or shall, with any Net, Instrument, or Engine, or with the Hand or otherwise, drag or fish upon the Ground or Soil of any such Mussel-Bed, Scalp Laying, or Fishery, every such Person shall be deemed guilty of an Attempt to commit Theft, and being convicted thereof before the Sheriff of the County shall be liable to be punished by Fine or Imprisonment, or both, as the Court shall award, such Fine not to exceed Ten Pounds, and such Imprisonment not to exceed Three Calendar Months.

III. Provided always, and be it enacted, That nothing in this Act contained shall prevent any Person, lawfully entitled there to fish, from fishing for or catching any floating Fish within the Limits of any Mussel Fishery, with any Net, Instrument, or Engine adapted for taking floating Fish only.

IV. Provided always, and be it enacted, That nothing in this Act contained shall prevent or be construed to prevent any Person from exercising any Right possessed by such Person of taking Bait, or any other Right which may now be lawfully exercised by such Person within the Limits of any such Fishery.

${ }^{1}[\mathrm{~V}$. And be it enacted, That this Act may be amended or repealed by any Act to be passed during this present Session of Parliament.]

1 Repealed by the Revision Act of 1875 . 


\section{APPENDIX B}

\section{EXCERPT FROM THE \\ FISHERY BOARD FOR SCOTLAND REGULATIONS}

FOR

The Instruction and Guidance of PERsons applying for Fishery ORders under Part III. of The Sea Fisheries Act, I868 (3 I \& 32 Vict. Cap. 45), The Fisheries (Oyster, Crab, and Lobster) Act, I877 (40 \& 4I Vict. Cap. 42), The Sea Fisheries (Clam and Bait Beds) Act, I88 I (44 Vict. Cap. II), and the Sea Fisheries (Scotland) Amendment Act, I 885 (48 \& 49 Vict. Cap. 70, § I I).

The Fishery Board for Scotland, to whom the administration of the above Acts has been transferred from the Board of Trade by the Sea Fisheries (Scotland) Amendment Act, I885 ( 48 \& 49 Vict. Cap. 70, § II), have made the following Regulations for the purpose of facilitating and systematising applications under their provisions.

* $* * \quad * \quad * \quad *$

PART I.-General Principles on which exclusive Rights of Fishery or Regulative Powers over Oyster and Mussel Fisheries will be granted.

The following comprise grants or concessions which appear to the Fishery Board to fall within the scope and 
intention of the above-named Acts, and for which they will be prepared to consider applications :-

I. Appropriations of moderate areas of unproductive sea bed or foreshore for the establishment of new fisheries or local depots.

2. Appropriations of areas of already productive ground for layings or depots.

3. Concessions of exclusive fishery rights to owners or occupiers of existing fisheries, but within such limits and conditions only as may make such concessions beneficial to the public.

4. Powers for regulating or restricting unlimited fishing on beds in cases where it is proved that such fishing is carried on in so wasteful a manner as to have the effect of exhausting the beds and diminishing the supply, without corresponding advantage to the public.

The only ground for the concession of exclusive fishery rights or restrictive powers over any portion of the seashore is the expectation that by these means the supply of oysters and mussels will be materially increased, and the public thereby benefited. Such expectation must consequently be shown to exist in all cases of Orders under these Acts, and especially in the case of an Order affecting an a ready productive dredging ground.

\section{PART II.-Title to Solum.}

This in every case will require to be instructed, so as to prevent invasion of the rights of others.

By the Crown Lands Act, I866 (29 \& 30 Vict. c. 62, $\$ 7$ to 25 ), the administration of the Crown rights over the foreshore and bed of the sea, where such rights exist, are, with certain exceptions, transferred to the Board of Trade. The Crown is also the conservator of rights of navigation.

The Board of Trade have intimated, that in cases where an application for a fishery grant includes foreshore or sea bed under their management, that Board will carefully 
abstain from throwing obstacles in the way of improvements of oyster and mussel fishings which will benefit the public, and will be averse to imposing any such terms as may, especially in the infancy of an undertaking, impede or delay its progress.

They will be prepared to consider favourably proposals founded on the basis of determining rent or royalty according to the profits actually made, or the quantity of oysters or mussels produced or sold by the promoters.

PART III.--Form of Procedure in applying for an Order under Part III. of The Sea Fisheries Act, I868.

I. The first step on the part of the promoters is to transmit a memorial to the Fishery Board for Scotland, as directed by Section 29 of the Act. The memorial should be transmitted in duplicate, written on common foolscap paper, on one side of the paper only, with a wide margin, and should contain the following information :-

(a) A description of the existing conditions of the proposed fishery,-whether it is barren or cultivated, and to what extent; and whether it contains any public or private beds, and in what condition.

(b) A statement of the manner in which it is intended to cultivate the ground applied for.

(c) In the case of an Order for a concession of or for regulating a fishery, a precise statement of the nature of the proposed regulations; of the proposed tolls (if any); of the manner in which they are to be levied and expended; and of the constitution of the corporation or other body by whom the powers in question are to be exercised.

(d) A statement of the means in the shape of income or capital possessed or anticipated by the promoters for this purpose.

(e) The names of the owners or reputed owners, lessees or reputed lessees, and occupiers of the soil 
included in the proposed fishery; and the nature of their title.

(f) Whether any, and if so what, arrangements have been or are proposed to be made with them.

The memorial should be also accompanied by the following documents :-

(i) Where the promoters are a company registered under The Companies Act, I862, by a printed copy of the memorandum of association, articles of association, and any registered special resolution of the company.

(ii) When they are a company formed in any other manner, by a copy of every deed or instrument of settlement, partnership or incorporation, or Act of Parliament, relating to the Company.

(iii) Where the promoter or promoters is or are the proprietor or proprietors by his or their title.

(iv) In every instance by a plan in quadruplicate upon an ordnance map or other chart of the locality, defining accurately the position, area, and boundaries of the ground proposed to be taken, showing what part is above and what below lowwater mark, and what part, if any, is above highwater mark. In this map or chart all portions of the sea bed or estuary below low-water mark not comprised in the proposed fishery are to be coloured blue, and the proposed fishery itself pink, and the area should be stated either in acres or by other measurement.

(v) In cases where the construction of works, such as piers, jetties, etc., is contemplated, by a plan and sections, and estimate for such works, signed by the persons making the same.

(vi) If the construction of tanks or other similar works of a permanent nature is contemplated, they should be described in the memorial; their dimensions should be given and their site should be shown on the plan of the fishery. 
2. The whole of the foregoing information should be classified under separate headings in the manner above shown; and the attention of promoters is called to the fact that statements contained in the memorial may, at a subsequent stage of the Order, become the subject of local investigation.

3. If after receiving the memorial the Fishery Board for Scotland decide to proceed with the case, the promoters will be required, in accordance with the Act (Section 30), to transmit, in duplicate, a draft of the proposed Order, printed on foolscap paper, on one side of each page only, and with a wide margin. Specimen forms of Orders are annexed. ${ }^{1}$ Further assistance may be derived from a perusal of Orders already confirmed.

An Order made by the Fishery Board for Scotland may include, if desirable, provisions for the constitution of a board or body corporate for the purpose of such Order. See Section 29.

4. The promoters will be required to make satisfactory arrangements for the expenses of the Order, the amount of which will depend on the nature of the application and the travelling and personal expenses of the inspector when making the inquiry directed in the 32nd section of the Act. The Fishery Board for Scotland will make these expenses as light as possible.

5. The draft Order, with such modifications as the Fishery Board for Scotland may require, must be circulated as follows; viz. :-

(a) Twelve copies must be deposited at the office of the Board.

(b) One copy must be deposited, and lie for public inspection free of charge during the month following the date of the first advertisement mentioned below, at the custom-house of the port, and also of the sub-port or creek, if any, within or adjacent to which the proposed fishery

1 See in this Appendix at pp. $1 \mathbf{r} 6$ and 119 , or in official Instructions, pp. 14,15 , and 16 . 
is situate ; together with one copy of the plan or ordnance map or chart of the locality showing the limits of the proposed fishery; and two copies of the plan and of the book of reference thereto deposited (if any).

(c) A sufficient number of copies of the draft Order must also be deposited at a local office to be named in that behalf in the advertisement mentioned below; such copies to be sold at a charge not exceeding Is. each; and facilities must be given at such office for the inspection of the plans.

6. The promoters must also give notice of the application by public advertisement, to be inserted twice at least in a county or other local newspaper. The advertisement must contain a statement, in an abridged form, of all the principal objects of the Order. It must also give the address of the local office where the draft Order can be seen and obtained, and an intimation that written objections will be received by the Fishery Board for Scotland during the month following the date of its publication.

7. The promoters must also cause copies of such advertisement to be posted up in conspicuous type, in the form of notices or placards, in at least six places in the neighbourhood of the proposed fishery, where they may be seen by fishermen and others interested in the undertaking; and, if the Fishery Board for Scotland so require, at other places.

8. Copies of the advertisement must also be forwarded by post to or left at the residences of the owners or reputed owners, lessees or reputed lessees, and occupiers (if any) of the portion of the sea-shore to which the draft Order relates, and of the lands adjoining thereto.

9. During the month following the date of the first advertisement of the draft Order the Fishery Board for Scotland will receive any objections or representations made to them respecting the same. All such objections must be transmitted in duplicate, written on common fools- 
cap paper on one side of the page only, and with a wide margin. A copy of such objections must also, at the same time, be sent to the promoters ; and in sending the objections to the Fishery Board for Scotland the objectors or their agents should state that this has been done. A copy of this rule must be printed at the foot of each draft Order.

Io. No Order, when granted, will entitle the promoters to interfere with any lawful purpose of navigation or anchorage (see Section 53 of the Act). Nor will the Fishery Board for Scotland be disposed to entertain any application which interferes sensibly or materially with the enjoyment and use of the shore for purposes of walking, bathing, boating, beaching, or landing.

II. As soon as conveniently may be, after the expiration of the said month, the Fishery Board for Scotland will arrange for a sitting or sittings being held in some suitable place in the neighbourhood of the proposed Fishery, and to take and receive evidence, on oath or otherwise, and imformation offered, as provided for in the 32 nd section of the Act. Notice of such sitting or sittings will be published in one or more local newspapers at least I4 days before the holding thereof.

12. On the report of the inspector, the Fishery Board for Scotland will either refuse the application, or make the Order in such form and manner as they think expedient; and, in the latter case, the Order, so approved, is to be advertised and circulated in the manner already pointed out with regard to the draft Order.

13. The Fishery Board for Scotland will arrange that Orders thus made, advertised, and circulated will afterwards be submitted for the sanction of Parliament, as directed in Sections 37 and 38 of the Act of I868, or of Her Majesty in Council for confirmation under the Act of $1877, \S 7$.

14. In the Order the Fishery Board for Scotland may insert provisions repealing or amending all or any of the provisions of a temporary Order for the protection of Bait Beds under the Act of I88I after mentioned, 44 Vict. c. I I, $\$ 6$. 
[Part IV., relating to restrictions on oyster dredging, and Part V., restrictions as to crabs and lobsters, have been omitted from this Appendix.]

PART VI.-Temporary Orders to protect Clam or other Bait Beds from injury by any Beam Trawl not being a dredge for Oysters.

For the purposes of such an Order, the local inquiry, confirmation, and other details enacted as regards Oyster and Mussel Fisheries under $\S \S 30$ to 39 both inclusive, $\S \S 42$ and $43, \S 46$, and $\S \S 48$ to 50 both inclusive, of the Act of 1868 are made to apply with the necessary modifications.

Accordingly it is only necessary to refer to these details as above set out in Part I. hereof.

\section{WM. C. ROBERTSON, Secretary.}

Fishery BOARD FOR SCOTLAND,

EDINBURgh, December I892.

SEA FISHERIES ACT, I868.

3I \& 32 Vict. CAP. XLV.

An Act to carry into effect a Convention between Her Majesty and the Emperor of the French concerning the Fisheries in the Seas adjoining the British Islands and France, and to amend the Laws relating to British Sea Fisheries. [1 3 th July I 868 .]

Note.-The powers and duties committed in this and the following Acts to the Board of Trade, so far as they can be exercised in Scotland, having by the Sea Fisheries (Scotland) Amendment Act, I 885 , been transferred to the Fishery Board for Scotland, the name of that Board will be substituted for that of the Board of Trade wherever it occurs in the following clauses. 


\section{PART III.}

\section{OYSTER Fisheries.}

\section{Preliminary.}

27. This part of this Act shall not interfere with the Part III. not jurisdiction or powers now possessed by the Irish Fishery to apply to! Commissioners with regard to oyster fisheries, and shall stated. not apply to Ireland, the Isle of Man, or the Islands of Guernsey, Jersey, Alderney, or Sark, or their dependencies, or to the seas adjoining the same, within the exclusive fishery limits of the British islands, or to any seas outside of those exclusive fishery limits.

28. In this part of this Act the words 'oysters' and Interpreta'mussels' respectively include the brood, ware, half-ware, tain terms. spat, and spawn of oysters and mussels respectively.

In this part of the Act the expression 'oyster and mussel fishery' includes a fishery for either oysters or mussels separately, and the term 'oyster or mussel fishery' includes a fishery for both oysters and mussels; and the provisions of this part of this Act shall be construed to apply in the case of any fishery to oysters and oyster ground and beds alone, or to mussels and mussel ground and beds alone, or to both oysters and mussels and oyster and mussel ground and beds, according as the right of fishery is for oysters alone, or for mussels alone, or for both oysters and mussels.

\section{Order for Fishery.}

29. An Order for the establishment or improvement, and Power to for the maintenance and regulation, of an oyster and mussel Board of fishery on the shore and bed of the sea, or of an estuary or memorial to tidal river, above or below, or partly above and partly below for oyster low-water mark (which shore and bed are in this part of fishery. this Act referred to as the sea-shore), and including, if desirable, provisions for the constitution of a board or body corporate for the purpose of such Order, may be made under this part of this Act, on an application by a memorial in that behalf presented to the Board of Trade by any 
Publication of draft Order and notice to owners of adjoining lands, etc.
Objections and representations respecting Order.

Inquiry into proposed Order by public sittings.

persons desirous of obtaining such an Order (which persons are in this part of this Act referred to as the promoters).

30. If on consideration of the memorial the Board of Trade think fit to proceed in the case, the promoters shall cause printed copies of the draft of the Order as proposed by them (with such modifications, if any, as the Board of Trade require) to be published and circulated in such manner as the Board of Trade think sufficient and proper for giving information to all parties interested, and shall give notice of the application, in such manner as the Board of Trade direct or approve, to the owners or reputed owners, lessees or reputed lessees, and occupiers (if any) of the portion of the sea-shore to which the proposed Order relates, and of the lands adjoining thereto.

3I. During one month after the first publication of the draft Order the Board of Trade shall receive any objections or representations made to them in writing respecting the proposed Order.

32. The Board of Trade shall, as soon as conveniently may be after the expiration of the said month, appoint some fit person to act as inspector respecting the proposed Order.

The inspector shall proceed to make an inquiry concerning the subject-matter of the proposed Order, and for that purpose to hold a sitting or sittings in some convenient place in the neighbourhood of the portion of the sea-shore to which the proposed Order relates, and thereat to take and receive any evidence and information offered, and hear and inquire into any objections or representations made respecting the proposed Order, with power from time to time to adjourn any sitting ; and the inspector may, for the purpose of such inquiry, take evidence, and by summons under his hand require the attendance of any person, and examine him and any person who attends before him, on oath or otherwise, as he thinks expedient, and may administer an oath or take any affidavit or declaration for the purpose of the inquiry; and any person so summoned who, after tender to him of his reasonable expenses, refuses 
or neglects to obey such summons, and any person who refuses or neglects to answer any question which the inspector is authorised to ask, shall be liable, on summary conviction, to a penalty not exceeding ten pounds for each offence; and any person who wilfully gives false evidence in any examination on oath in any such inquiry, or in an affidavit or declaration to be used in any such inquiry, shall be deemed guilty of perjury.

Notice shall be published in such manner as the Board of Trade direct of every such sitting (except an adjourned sitting) fourteen days at least before the holding thereof.

33. The inspector shall make a report in writing to the Report of Board of Trade, setting forth the result of the inquiry, and Inspector as stating whether in his opinion the proposed Order should to proposed be approved, with or without alteration, and if with any, then with what alteration, and his reasons for the same, and the objections and representations, if any, made on the inquiry, and his opinion thereon.

34. As soon as conveniently may be after the expiration Settlement of the said month, or after the receipt by the Board of and making Trade of the report of the Inspector, they shall proceed to consider the objections or representations that have been made respecting the proposed Order and also the report of the inspector, and thereupon they shall either refuse the application or settle and make an Order in such form and containing such provisions as they think expedient.

35. Where the Board of Trade make an Order, the pro- Publication moters shall cause it to be published and circulated in such of Order. manner as the Board of Trade think sufficient for giving information to all parties interested, and shall give notice of it, in such manner as the Board of Trade direct or approve, to the owners or reputed owners, lessees or reputed lessees, and occupiers (if any) of the portion of the sea-shore to which the Order relates, and of the lands adjoining thereto.

36. All expenses incurred by the Board of Trade in rela- Expenses tion to any memorial, or to any Order consequent thereon, $\begin{aligned} & \text { connected } \\ & \text { with Order }\end{aligned}$ shall be defrayed by the promoters, and the Board of Trade 
shall, if they think fit, on or at any time after the presentation of the memorial, require the promoters to pay to the Board of Trade such sum as the Board of Trade think requisite for or on account of those expenses, or to give security to the satisfaction of the Board of Trade for the payment of those expenses on demand.

Confirmation of Order by Act of Parliament.

Power to refer Order to a Select Committee if opposed.

As to amend. ment of Order by Board of Trade.

Effect of grant of several oyster fishery.

37. An Order of the Board of Trade under this part of this Act shall not of itself have any operation, but the same shall have full operation when and as confirmed by Act of Parliament, with such modifications, if any, as to Parliament seems fit.

38. If in the progress through Parliament of a Bill confirming an Order a petition is presented to either House of Parliament against the Order, the Bill, as far as it relates to the Order petitioned against, may be referred to a Select Committee, and the petitioner shall be allowed to appear and oppose as in case of a Private Bill.

39. The Board of Trade may from time to time make an Order for amending an Order that has been confirmed by Act of Parliament, and all the provisions of this part of this Act relative to an original Order shall apply also to an amending Order, mutatis mutandis.

40. Where an Order of the Board of Trade under this part of this Act confers a right of several oyster and mussel fishery, the persons obtaining the Order, in this Act referred to as the grantees, shall, by virtue of the Order and of this part of this Act, but subject to any restrictions and exceptions contained in the Order, have, within the limits of the fishery, the exclusive right of depositing, propagating, dredging, and fishing for, and taking oysters and mussels, and in the exercise of that right may, within the limits of the fishery, proceed as follows, namely, make and maintain oyster and mussel beds, or either of them, and at any season collect oysters and mussels, and remove the same from place to place, and deposit the same as and where they think fit, and do all other things which they think proper for obtaining, storing, and disposing of the produce of their fishery. 
4I. Where an Order of the Board of Trade under this Effect of part of this Act, without conferring a right of several oyster $\begin{gathered}\text { grant of } \\ \text { power of }\end{gathered}$ and mussel fishery, confers a right of regulating an oyster regulating and mussel fishery, and imposes restrictions on or makes regulations respecting the dredging and fishing for and taking oysters and mussels, or either of them, within the limits of the regulated fishery, or imposes tolls or royalties upon persons dredging, fishing for, and taking oysters and mussels, or either of them, within the limits of such fishery, the persons obtaining the Order, in this Act included in the term the grantees, shall by virtue of the Order and of this part of this Act, but subject to any restrictions and exceptions contained in the Order, have power to do all or any of the following things, namely :-

(a) To carry into effect and enforce such restrictions and regulations :

(b) To levy such tolls or royalties :

(c) To provide for depositing and propagating oysters and mussels within the limits of the fishery, and for improving and cultivating the fishery.

All such restrictions, regulations, tolls, and royalties shall be imposed on and apply to all persons equally, and shall be for the benefit of the fishery only, and the tolls and royalties shall be applied in the improvement and cultivation of the fishery.

Any person who dredges or fishes for or takes any oysters or mussels in contravention of any such restriction or regulation, or without paying any such toll or royalty, shall be liable on summary conviction to pay a penalty not exceeding twenty pounds, and to forfeit all oysters and mussels so taken, or a sum equal to the value thereof if they have been sold, which forfeiture may be enforced in the same manner as a penalty.

The Court may direct such forfeiture to be delivered or paid to the grantees, to be applied by them for the improvement and cultivation of the fishery.

42. Whenever it is necessary in any legal proceeding to Proof of prove that, in pursuance of any Act of Parliament or of marking of 
an Order under this part of this Act, the limits of any oyster and mussel fishery have been duly buoyed or otherwise marked, or notices of such limits have been duly published, posted, or distributed, or that notice of the provisions of the Order or of such Act relating to the oyster and mussel fishery has been duly published, a certificate purporting to be under the hand of one of the secretaries or assistant secretaries of the Board of Trade, certifying that the Board of Trade are satisfied that the said limits were so buoyed or marked, or that the said notices were duly published, posted, or distributed, shall be received as evidence that the same have been so buoyed or marked, or that the said notices have been so published, posted, or distributed.

Fishery to be within county for purposes of jurisdiction.

Limitation on term of several fishery.

Condition for cesser of several fishery, if no adequate benefit.

43. The portion of the sea-shore to which an Order of the Board of Trade, under this part of this Act, relates (as far as it is not by law within the body of any county) shall for all purposes of jurisdiction be deemed to be within the body of the adjoining county, or to be within the body of each of the adjoining counties, if more than one.

44. The Board of Trade shall not in any case make an Order conferring a right of several oyster and mussel fishery, or a right of regulating an oyster and mussel fishery, for a longer period at once than sixty years.

45. A right of several oyster or mussel fishery conferred by an Order of the Board of Trade under this part of this Act, or by 'The Roach River Oyster Fishery Act, I866,' and a right of regulating an oyster and mussel fishery, shall, notwithstanding anything in the Order or in the said Act, be determinable by a certificate of the Board of Trade (which certificate they are hereby empowered to make) certifying to the effect that the Board of Trade are not satisfied that the grantees under the Order, or the company under the said Act (as the case may be), are properly cultivating the oyster or mussel ground within the limits of such fishery, or are properly carrying into effect and enforcing the restrictions and regulations, and levying the tolls or royalties; and on any such certificate being made, 
the right of several fishery or right of regulating the fishery (as the case may be) by such order or the said Act conferred shall, by virtue of this part of this Act, and of the certificate, be absolutely determined, and all provisions of this part of this Act, or of the said Act, shall cease to operate in relation to such fishery as a several oyster and mussel fishery or as a regulated fishery.

For the purposes of this provision the Board of Trade may from time to time, with respect to any such fishery, make such inquiries and examination by an inspector or otherwise, and require from the grantees or company such information as the Board of Trade think necessary or proper, and the grantees or company shall afford all facilities for such inquiries and examination, and give such information accordingly.

46. Where any portion of the sea-shore proposed to be Consent with comprised in an Order of the Board of Trade under this part of this Act belongs to Her Majesty, Her heirs or successors, in right of the Crown, but is not under the management of the Board of Trade, or forms part of the ${ }_{\text {wall. }}^{\text {and Corn- }}$ possessions of the Duchy of Lancaster or of the Duchy of Cornwall, the Board of Trade shall not make the Order without such consent as hereinafter mentioned, namely :-

In the first-mentioned case of the Commissioners of Her Majesty's Woods, Forests, and Land Revenues, or one of them :

In the secondly-mentioned case of the Chancellor of the Duchy of Lancaster in writing under his hand attested by the clerk of the council of the Duchy :

In the thirdly-mentioned case of the Duke of Cornwall, or other the persons for the time being empowered to dispose for any purpose of lands of the Duchy of Cornwall.

47. Where any portion of the sea-shore comprised in an CompensaOrder of the Board of Trade under this part of this Act tion to landdoes not belong to Her Majesty, Her heirs or successors, in right of the Crown, or form part of the possessions of the Duchy of Lancaster or of the Duchy of Cornwall, the

respect to rights of the Crown or
Duchies of Lancaster 
Board of Trade shall incorporate in the Order 'The Lands Clauses Consolidation Act, I845,' or 'The Lands Clauses Consolidation (Scotland) Act, I845,' as the case requires, and shall apply the provisions thereof respectively to the purchase or taking of such portion of the sea-shore.

Order of

Board of

Trade not to abridge right of several fishery, etc.

Copies of Orders and Acts printed by Queen's printer to be kept for sale. report of Board of Trade.

48. No Order made by the Board of Trade under this part of this Act shall take away or abridge any right of several fishery, or any right on, to, or over any portion of the sea-shore, which right is enjoyed by any person under any Local or Special Act of Parliament, or any royal charter, letters-patent, prescription, or immemorial usage, without the consent of such person.

49. The persons obtaining an Order under this part of this Act shall at all times keep at some convenient place, in the neighbourhood of the portion of the sea-shore to which the Order relates, copies of the Order with the Act confirming it, and of this part of this Act, printed respectively by some of Her Majesty's printers, and shall sell such copies to all persons desiring to buy them at a price not exceeding sixpence for one copy of this part of this Act and of the Order and of the Act confirming it together.

If any such persons fail to comply with this provision they shall for every such offence be liable to a penalty not exceeding five pounds, and to a further penalty not exceeding one pound for every day during which such failure continues after the day on which the first penalty is incurred.

50. There shall be annually laid before both Houses of Parliament a report of the Board of Trade respecting the applications to and proceedings of the Board of Trade under this part of this Act during each year.

\section{Protection of Oyster Beds.}

Property in oysters, etc., within several fishery.
5I. All oysters and mussels being in or on an oyster or mussel bed within the limits of a several oyster and mussel fishery granted by an Order under this part of this Act, and all oysters being in or on any private oyster bed which is owned by any person independently of this Act, and is 
sufficiently marked out or sufficiently known as such, shall be the absolute property of the grantees or of such owner, as the case may be, and in all courts of law and equity and elsewhere, and for all purposes, civil, criminal, or other, shall be deemed to be in the actual possession of the grantees and such owner respectively.

52. All oysters and mussels removed by any person from Property in an oyster or mussel bed within the limits of any such several fishery, and all oysters removed by any person from any such private oyster bed, and not either sold in market overt or disposed of by or under the authority of the grantees or owner (as the case may be), shall be the absolute property of the grantees and owner respectively, and in all courts of law and equity and elsewhere, and for all purposes, civil, criminal, or other, the absolute right to the possession thereof shall be deemed to be in the grantees and owner respectively.

53. It shall not be lawful for any person other than the Protection grantees, their agents, servants, and workmen within the of several: limits of any such several fishery, or in any part of the space within the same described in this behalf in the Order, or other than the owner of any such private oyster bed, his agents, servants, and workmen, within the limits of such bed, knowingly to do any of the following things :

To use any implement of fishing except a line and hook or a net adapted solely for catching floating fish, and so used as not to disturb or injure in any manner any oyster or mussel bed, or oysters or mussels, or the oyster or mussel fishery :

To dredge for any ballast or other substance, except under a lawful authority for improving the navigation :

To deposit any ballast, rubbish, or other substance :

To place any implement, apparatus, or thing prejudicial or likely to be prejudicial to any oyster or mussel bed, or oysters or mussels, or to the oyster or mussel fishery, except for a lawful purpose of navigation or anchorage : 
To disturb or injure in any manner, except as last aforesaid, any oyster or mussel bed, or oysters or mussels, or the oyster or mussel fishery :

And if any person does any act in contravention of this section he shall be liable to the following penalty, namely, to a penalty not exceeding two pounds for the first offence, and not exceeding five pounds for the second offence, and not exceeding ten pounds for the third and every subsequent offence ; and every such person shall also be liable to make full compensation to the grantees and owner respectively for all damage sustained by them or him by reason of his unlawful act, and in default of payment the same may be recovered from him by the grantees and owner respectively by proceedings in any court of competent jurisdiction (but not in a summary manner), whether he has been prosecuted for or convicted of an offence against this section or not.

Limits of

fishery to be kept marked out.

Contiguous fisheries.
54. Provided always, that nothing in the last foregoing section shall make it unlawful for any person to do any of the things therein mentioned,-

(a) In the case of a fishery granted by an Order under this part of this Act, if at the time of his doing the same the limits of the several fishery or of the space within the same described in that behalf in the Order are not sufficiently marked out in manner prescribed by or under the Order, or if notice of those limits has not been given to him in manner so prescribed:

(b) In the case of a private oyster bed owned by any person independently of this Act, if it is not sufficiently marked out and known as such.

55. When two or more oyster or mussel beds or fisheries belonging to different proprietors are contiguous to each other, and any proceeding by indictment or otherwise is taken against any person for stealing oysters or mussels from any bed formed under an Order made in pursuance of this part of this Act, or for stealing oysters from any bed formed independently of this Act, it shall be sufficient, in alleging and proving the property and lawful possession of 
the oysters or mussels stolen, and the place from which they were stolen, to allege and prove that they were the property of and in the lawful possession of one or other of such proprietors, and were stolen from one or other of such contiguous beds or fisheries.

56. This part of this Act shall, as to all Orders made Application under the Oyster and Mussel Fisheries Act, I 866, which Orders, etc., have been or may be confirmed in this Session of Parlia- under 29 and ment, apply in the same manner as if they had been made and confirmed in pursuance of this part of this Act.

All Orders made under the Oyster and Mussel Fisheries Act, I 866, before the commencement of this Act, and not so confirmed, and all proceedings taken before the commencement of this Act with a view to obtain any such Orders, shall have effect and be proceeded with as if they had been respectively made and taken under this part of this Act.

\section{SEA FISHERIES (CLAM AND BAIT BEDS)}

$$
\begin{gathered}
\text { ACT, I88I. } \\
\text { [44 VICT. CAP. II.] }
\end{gathered}
$$

An Act to further amend the Law relating to Sea Fisheries by providing for the protection of Clam and other Bait Beds. [3d June I881.]

I. This Act may be cited as the Sea Fisheries (Clam and Short title. Bait Beds) Act, I88I.

2. Where the Board of Trade, on such application and Power of after such local inquiry as in this Act mentioned, are satisfied Trade by that the unrestricted use of beam trawls in any area being Provisional part of the sea adjoining the United Kingdom, and within tect bait beds the territorial waters of Her Majesty's dominions, within the from injury meaning of the Territorial Waters Jurisdiction Act, 1878, is trawls. injurious to any clam or other bait bed in that area, the $4 \mathrm{I}$ and 42 Board of Trade may make an Order for restricting or prohibiting or for empowering the authority named therein to restrict or prohibit, either entirely or subject to such regulations as may be provided by the Order, the use of any 
beam trawl for taking sea fish within the area named in the Order during such term of years, or during such period either in every year or in a term of years, as is limited by the Order.

The Board of Trade may, by any such Order, provide for enforcing the Order, and any restriction, prohibition, or regulation contained therein, by fines not exceeding twenty pounds for each offence; and the authority empowered by the Order may be any person or body of persons corporate or unincorporate, and may, if it seem expedient, be constituted by the Order.

An Order under this section shall be subject to such confirmation by Parliament or otherwise as in this Act mentioned.

Persons who may apply for Order.
Application of provisions of $3 \mathrm{r}$ and $3^{2}$ Vict. c. 45 , relating to Orders of th Board of Trade.
3. An application to the Board of Trade for an Order under this Act in relation to any locality may be made by memorial in that behalf presented to the Board of Trade by any persons appearing to the Board of Trade to represent the fishermen of the locality, or by any of the following authorities, if they appear to the Board of Trade to be interested in the fisheries of the locality ; namely,-

The justices of a county in general or quarter sessions assembled; or in Scotland the Commissioners of Supply of any county :

A town council or other urban sanitary authority :

A rural sanitary authority : and

Any body corporate, persons or person being or claiming to be proprietors or proprietor of or intrusted with the duty of improving, managing, maintaining, or regulating any harbour.

4. For the purposes of an Order under this Act, and the local inquiry, confirmation, and other matters in reference thereto, sections thirty to thirty-nine (both inclusive), sections forty-two and forty-three, section forty-six, and sections forty-eight to fifty (both inclusive), of the Sea Fisheries Act, I868, shall apply as if those sections were re-enacted in this Act with the necessary modifications; and with the substitution of the applicants for an Order under this Act for the 'promoters.' 
Provided, that where an Order made under this Act either is limited to an area not exceeding five acres, or amends a previous Order without extending the area to which that order implies, and a petition against the Order by any local authority or persons affected thereby is not within one month after the first publication of the Order received by the Board of Trade, or if received is withdrawn, the Board of Trade may, if they think fit, submit the Order for confirmation to Her Majesty in Council ; and every such Order, if confirmed by Her Majesty in Council, shall have full operation as if it had been confirmed by Parliament.

5. An Order made under this Act, and confirmed by Power to Order in Council, may, notwithstanding anything in the Oetermin Order, be determined either wholly or partially at any time by Her Majesty in Council on the representation of the Board of Trade (which the Board may make after such inquiry as they may think necessary); and the authority empowered by the Order shall not be entitled to any compensation in respect of such determination or in respect of any expenses incurred by them in acting or with a view to act under the Order.

6. An Order made by the Board of Trade under Part III. Power in 6 . An of the Sea Fisheries Act, 1868, may, if the Board see fit, 3 rand $3^{2}$ contain provisions repealing or amending all or any of the Vict.c. 45 , provisions contained in an Order made under this Act.

7. This Act shall not extend to Ireland, but may be extended to the Isle of Man, if an Act shall be passed by the Act. Legislature of the said Isle adopting the same.

8. All fines and proceedings under this Act, or under any Recovery Order made and confirmed in pursuance of this Act, may be recovered and taken in the same manner as fines and proceedings are recovered and taken under the Sea Fisheries Act, I868, and any Act amending the same.

9. In this Act, unless the context otherwise requires, the Interpretaexpression 'beam trawl' means a net commonly known as a beam trawl net, and any other engine or instrument (not being a dredge for oysters) which is used or capable of being used for dragging along the bottom of the sea for the purpose of taking fish. 
SEA FISHERIES (SCOTLAND) AMENDMENT

$$
\begin{gathered}
\text { ACT, } 1885 . \\
{[48 \& 49 \text { VICT. CAP. 70.] }}
\end{gathered}
$$

An Act to amend the Law relating to Scottish Sea Fisheries and for other purposes relating thereto.

II. All the powers and duties of the Board of Trade so far as they can be exercised in Scotland with respect to-

(a) Oyster and mussel fisheries contained in the Sea Fisheries Acts, and the Fisheries (Oyster, Crab, and Lobster) Act, 1877 ;

(b) Crab and lobster fisheries contained in the last mentioned Acts ;

(c) Clam and bait beds contained in the Sea Fisheries (Clam and Bait Beds) Act, I88I, are hereby transferred to the Fishery Board.

\section{SPECIMEN FORMS OF ORDERS.}

(I) ORDer for the Establishment and Maintenance of an OYSTER or MUSSEL or OYSTER and MUSSEL Fishery.

(2) ORDER for the REgulation of an Oyster or MUSSEL or Oyster and MusSel Fishery.

Note.-By the 29th section of the Sea Fisheries Act, I868, and the IIth section of the Sea Fisheries (Scotland) Amendment Act, I885, an Order made by the Fishery Board for Scotland may include, if desirable, provisions for the constitution of a Board or Body Corporate for the purposes of the Order. 
(I) ORDER for the Establishment and Maintenance by the Company [Limited], of a Several Orster [or Mussel or Oyster and MUSSEL] FISHERY at in the Estuary of in the County of

I. The Oyster Company, Limited (in this Undertakers. Order called the Company), shall be the undertakers of the fishery mentioned in this Order.

2. For the purposes of the fishery and works authorised Power to by this Order, the Company may from time to time enter take specified on, take, and use all or any part of the lands described in the plans and book of reference deposited for the purposes of this Order.

3. The Lands Clauses Consolidation Act, I845, and The Lands Lands Clauses Consolidation Acts Amendment Acts, I860, Clauses Acts are hereby incorporated with this Order.

(If the land belongs to the Crown, Clauses 2 and 3 will be omitted.)

4. The following are the Company's fishery grounds Limits of under this Order (as shown on plans deposited at the fishery, and Fishery Board for Scotland); namely, all those parts of the foreshore and bed of the the several parishes of

$$
\text { , containing an area of }
$$

situate within , in the county of abouts; and bounded as follows: that is to say : or there(Here insert an accurate description of the locality, position, and boundary lines of the Fishery.)

5. This Order confers on the Company a right of several Right to oyster [or mussel or oyster and mussel] fishery within the several limits above mentioned.

6. The limits of the said several fishery shall be marked Marking of out as follows; that is to say :limits. 
Notice to be given.
Works not to be com. menced withFishery Board.

Company to give accounts of capital, receipts, and expenditure, and of oysters and mussels sold.

Time of operation.

Saving of rights under Crown Lands Act, 1866 .

Short title.

8. No buildings, erection, embankments, or other works, other than the marks mentioned in Article [6] of this Order, shall at any time be commenced, or executed within the limits above described without the previous sanction and approval in writing of the Fishery Board for Scotland, and of the Board of Trade.

9. The Company shall render to the Fishery Board for Scotland such accounts of their capital, expenditure, and income, and of all oysters [or mussels or oysters and mussels] sold by the Company, in such form and at such times as the Board may require, and shall allow the Board or any person appointed by them to inspect the fishery and all books and documents in their possession relating thereto, and shall give to such Board or person all such information relating thereto, as they or he may require.

Io. This Order shall continue in operation for years from its confirmation by Act of Parliament (or by Order of Her Majesty in Council), and no longer.

II. This Order shall not be taken as a consent to the surrender of any rights, interests, powers, authorities, or privileges transferred to the management of the Board of Trade by 'The Crown Lands Act, I 866.'

I2. This Order may be cited as The

Fishery Order, 18 .

Notice to Objectors.-During the month following the date of the first advertisement of the draft Order, the Fishery Board for Scotland will receive any objections or representations made to them respecting the same. All such ob- 
jections must be transmitted in duplicate, written on common foolscap paper on one side of the paper only, and with a wide margin. A copy of such objections must also, at the same time, be sent to the promoters; and in sending the objections to the Board, the objectors or their agent should state that this has been done.

(2) ORDER for the REGULATION by the CORPORATION of of an OYSTER [or MUSSEL or OYSTER and MUSSEL] FISHERY at Estuary of the in the in the County of

I. The Municipal Corporation of

(in this Undertakers.

Order called the Corporation) shall be the undertakers of this Order.

2. For the purposes of the fishery and works authorised Power to by this Order, the Corporation may from time to time enter takespecified on, take, and use all or any part of the lands described in the plans and book of reference deposited for the purposes of this Order.

3. The Lands Clauses Consolidation Act, I845, and the Lands Lands Clauses Consolidation Acts Amendment Act, I860, $\begin{aligned} & \text { Clauses Acts } \\ & \text { incorporated. }\end{aligned}$ are hereby incorporated with this Order.

\section{(If the land belong to the Crown, Clauses 2 and 3} will be omitted.)

4. The following are the description and limits of the Description fishery comprised in this Order (as shown on plans de- and limits of posited at the Fishery Board for Scotland); namely, all plans. those parts of the foreshore and bed of the situate within the several parishes of 
the county of , containing an area of or thereabouts ; and bounded as follows, that is to say :(Here insert an accurate description of the locality, position, and boundary lines of the Fishery.)

Powers conferred by Order.

Marking of limits.

Notice to be given.

5. This Order confers on the Corporation the following powers ; that is to say :-

6. The limits of the said fishery shall be marked out as follows ; that is to say :-

7. In the event of the marks by the last foregoing article prescribed being obliterated by storm or otherwise, they shall be replaced by the Corporation, and notice of the said limits may be given to fishermen, dredgermen, and other persons as follows ; that is to say :-

Works not to be com. menced with out assent of Fishery Board.

8. No buildings, erections, embankments, or other works, other than the works mentioned in article [6] of this Order, shall at any time be commenced or executed within the limits above described without the previous sanction and approval in writing of the Fishery Board for Scotland, and of the Board of Trade.

Corporation to give accounts of proceedings, income, and expenditure.

9. The Corporation shall render to the Fishery Board for Scotland such accounts of their proceedings under this Order, and of their income and expenditure thereunder, in such form and at such times as the Board may require, and shall allow the Board or any person appointed by them to inspect the fishery and all books and documents in their possession relating thereto, and shall give to such Board or person all such information relating thereto as they or he may require.

Time of operation.

I0. This Order shall continue in operation for years from its confirmation by Act of Parliament (or by Order of Her Majesty in Council), and no longer. 
II. This Order shall not be taken as a consent to the sur- Saving of render of any rights, interests, authorities, or privileges rights under transferred to the management of the Board of Trade by Act, 1866 . 'The Crown Lands Act, I866.'

12. This Order may be cited as The Fishery Short title. Order, 18 .

Notice to Objectors.-During the month following the date of the first advertisement of the draft Order, the Fishery Board for Scotland will receive any objections or representations made to them respecting the same. All such objections must be transmitted in duplicate, written on common foolscap paper on one side of the page only, and with a wide margin. A copy of such objections must also, at the same time, be sent to the promoters; and in sending the objections to the Fishery Board, the objectors or their agents should state that this has been done.

Printed by T. and A. Constable, Printers to Her Majesty at the Edinburgh University Press 
10 


$32044072211 \quad 428$ 
4. a

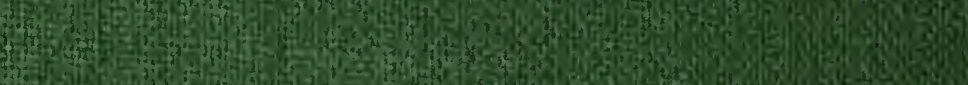

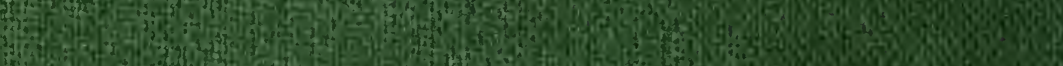

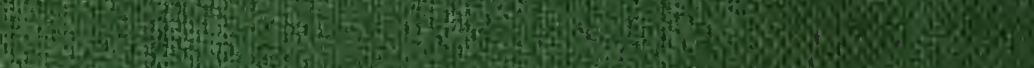

H.

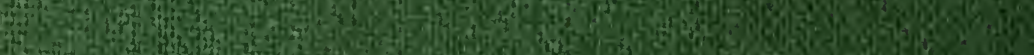

2.

की

25.

S.

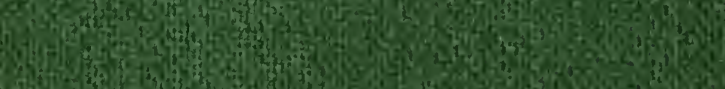

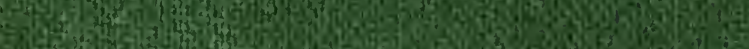

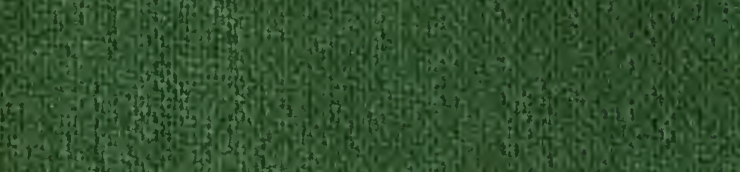

a

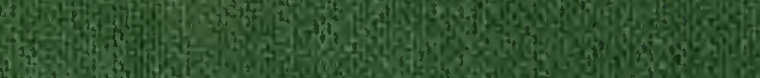

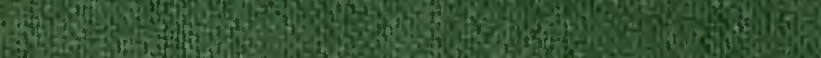

1.

41.

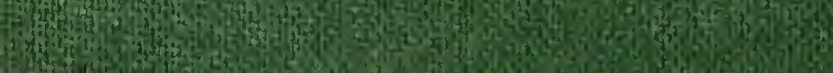

